\title{
5 \\ THE NEXT 10 DAYS: DISASTER RELIEF AND CONTROVERSY
}

\section{Monday 22 January: First Arrivals by Air and Sea}

Residents in Port Moresby 'awoke to a blanket of grey, gritty dust laying inches thick over everything. The air was so full of pumice dust that by 8 a.m. the opposite side of the bay was blotted out', reported the South Pacific Post $(1951 \mathrm{~b}, 1)$. The ash was from the strong eruption at Lamington on the previous evening and it was carried to the Territory's capital by the high-level east-west winds. Visibility was also poor at Port Moresby airport, Jacksons Airstrip, which had to be closed temporarily. It was open, however, for the later arrival of evacuees from Popondetta via Lae, and to ensure support for the required emergency relief effort into Popondetta, although much of this came from Lae.

Outside assistance for the still-living victims of the Sunday eruption in the Lamington area arrived in force from Port Moresby and Lae on the morning of Monday 22 January. The government trawler Huon had sailed from Lae on the previous evening and it arrived at Cape Killerton on the coast near Popondetta at around dawn (e.g. Blaikie 2006, 2007; Martin 2013). On board the Huon were administration and medical personnel and emergency supplies. The personnel included the district commissioner of Morobe District, H.L.R. 'Horrie' Niall, as well as patrol officers J.D. 'Des' Martin and R.W. 'Bob' Blaikie, together with Dr Max Sverklys, an Australian nurse Sister 'Rusty' Maclean and about six 
Papua New Guinean police. The party did not know what to expect, but after landing at the beach at Cape Killerton, unloading and then driving by truck to Popondetta they started to appreciate the impact and horror of the disaster. They encountered on the road a jeep and trailer being driven from Popondetta by Rodd Hart and heading to Gona carrying the body of Reverend Dennis Taylor in a coffin built by Father Benson who had arrived at Popondetta from Gona (Strong 1951).

Qantas aircraft carrying relief personnel and supplies began landing at Popondetta airstrip early on Monday (Qantas 1951; Henry 1951; Sinclair 1986; Bullard 2017). One aviation historian later wrote that these first flights into Popondetta represented the beginning of an:

Amazing, inspiring and superbly-coordinated work of rescue and evacuation ... [in which] the air companies of PNG, and in particular Qantas, played a vital part ... One hundred and seventy-five rescue personnel ... were flown in during this period. One of the principal needs was for clean drinking water, as all the streams in the area were heavily fouled with pumice dust. In total, the DC3s made 143 flights to the disaster area, carrying over 265,000 kilograms of supplies. Dragons made 117 flights, carrying over 53,000 kilograms. Virtually every Qantas pilot took part. (Sinclair 1986, 118-19; see also Civil Aviation 1951)

Senior administration personnel and their support staff began arriving early on the Monday by air, mainly from Port Moresby. Judge Phillips in Port Moresby had attempted to fly into Popondetta on the previous day, Sunday, but his aircraft had to turn back because of poor weather and the pervasive eruption cloud that could be seen 'coming towards Port Moresby, its upper part or layer extending, at 20,000 feet or so, many miles ahead of its lower layer. We flew under the upper layer, but were pressed westward by the lower mass' (Deputy Administrator 1951, appendix C, 1; see also Phillips 1951a). Phillips, however, flew into Popondetta the next day, Monday, at around midday, and found that Ivan Francis Champion, acting director of District Services and Native Affairs, and medical support staff led by Dr John T. Gunther, director of Public Health for the Territory, had arrived at the airstrip already and had begun organising the relief effort (e.g. South Pacific Post 1951b).

Ivan Champion had established a strong reputation as a government explorer in Papua when, in 1928 as a young patrol officer, he accompanied Charles H. Karius in a crossing of New Guinea island from the headwaters of the Fly River in the south to the Sepik River on the north coast, later publishing a successful book on the crossing in London 
(Champion 1932). Champion's reputation and fame continued to grow when, in 1938, he led the great Bamu-Purari patrol through the Papuan side of the formidable central cordillera of the Highlands area. He passed by impressive mountains whose volcanic origin had been recognised by earlier explorations undertaken by Champion's fellow officer and friend Jack Hide (Sinclair 1988). Champion's leadership skills, knowledge of local conditions throughout the Territory and many years of experience within the Papuan colonial administration would be applied successfully during the relief and recovery phases of the Lamington eruption in 1951.

The other senior administration officer at Popondetta, Dr Gunther, had been in Finschhafen on the Sunday of the eruption, but had flown into Popondetta the following morning. Gunther took on the overall responsibility for dealing with the medical and health aspects of the disaster, both immediate and subsequent, and so worked closely with Ivan Champion and others (Gunther 1951a, 1951b, 1951-52). He quickly set about assessing the disaster area on the ground. The Searles at Waseta were surprised to see Gunther arrive there by road from Popondetta later that afternoon after:

Quite a dangerous journey through constant ash and debris devastation, and possibly quickly rising rivers, to come so far to us ... coming into the huge area of death and destruction, urgently arranging the first emergency supplies so badly needed. (Searle 1995, 245)

Popondetta was confirmed by Champion and Gunther as the forward rescue, relief and evacuation centre for the area, as well as the main medical casualty centre, at least for the time being. Radio communications were established with Port Moresby and Australia. The Huon relief party from Lae reached Popondetta from Cape Killerton later on Monday and saw the extent of burns on the survivors who had been brought to the small settlement. Dr Sverklys and Sister McLean joined other Europeans who had already been attending to the victims still alive at Popondetta. Mission sisters Pat Durdin from Isivita and Jean Henderson from Eroro had also joined the medical team. Caring for the burnt people who had survived the trauma of the night at Popondetta was a priority. These casualties were mainly Orokaiva whose burns on their backs and on the backs of their legs were particularly severe, a result of their skin not being covered by clothes as they attempted to run from the encroaching ash cloud (Figure 5.1). Blood plasma for burns treatment was in short supply on this day but much of what little there was in Port Moresby had been brought to Popondetta. Severe cases were evacuated as soon as possible to Lae Hospital and some to Port Moresby. 


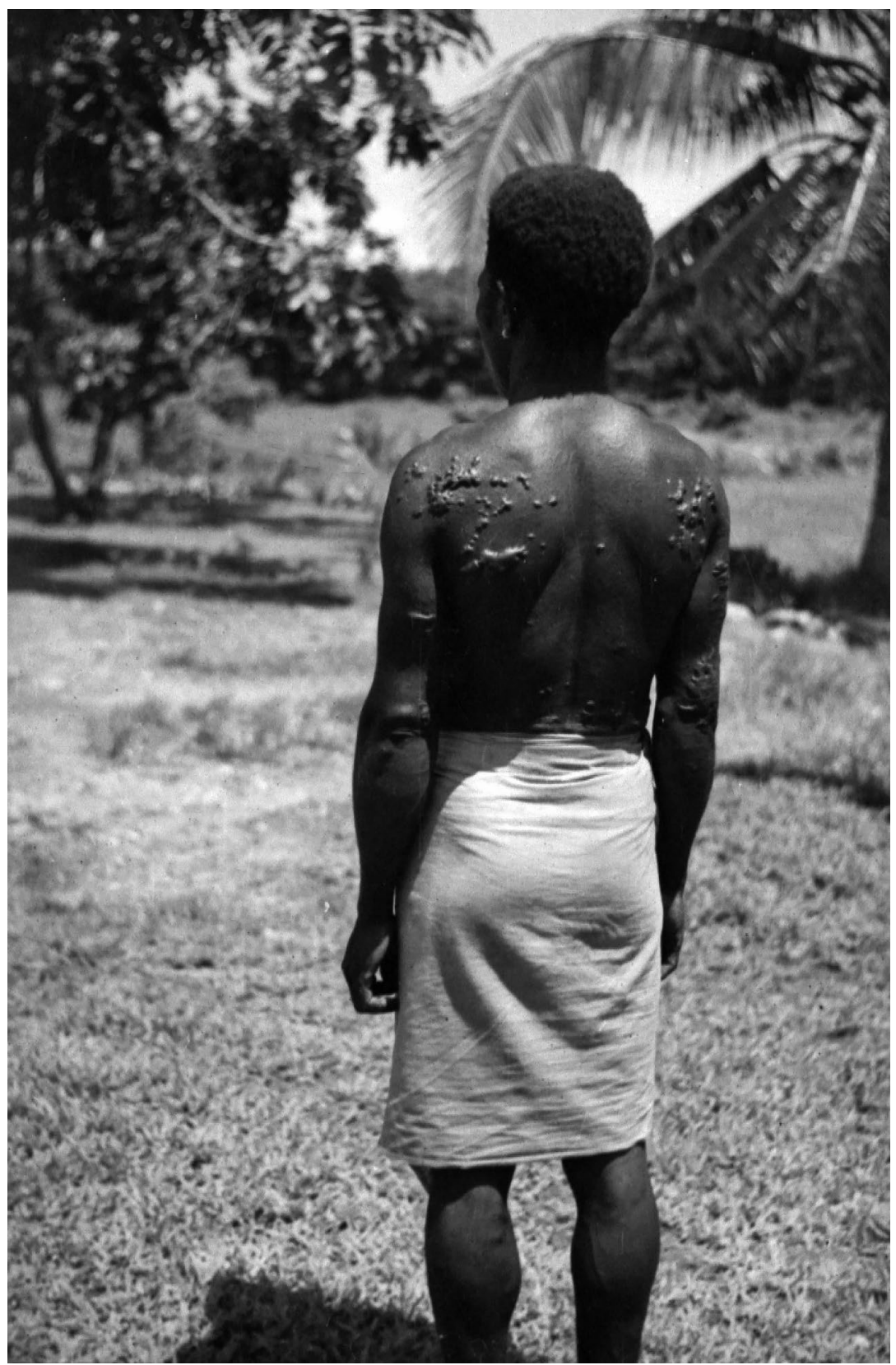

Figure 5.1. Healed burn scars on man's back

Healed burn scars inflicted by the 21 January ash flow are seen here on the back of a survivor (Taylor 1958, fig. 77). Photograph supplied courtesy of Geoscience Australia (negative number GA/8201). 
Ivan Champion established an Administration Field Group at Popondetta and immediately gave written instructions to subordinate officers W. Crellin, A.A. Roberts, F.P. Kaad and I. Holmes, and, two days later, to J.R. Foldi:

You are hereby instructed to do any act you may consider bona fide necessary to assist in the alleviation of suffering and the functioning of the Administration Field [Group] in the area under its control. (I. Champion 1951)

Other tasks begun by administration staff were identifying further casualties, collecting and burying the dead, and planning for the care of the survivors. Numerous survivors and evacuees had assembled in different areas, notably at Waseta and Popondetta, at Cape Killerton on the coast, at Inonda in the north-east and at Eroro on the coast. Assistant District Officer Kaad and Patrol Officer Morris went to Waseta to identify and establish an evacuation camp for the hundreds of refugees in that general area. A site was soon chosen at Wairopi on the low, western bank of the Kumusi River. Patrol Officer Bill Crellin was placed in charge of the refugees at Cape Killerton and Assistant District Officer Ian Holmes went to the Inonda airstrip to collect survivors there (Phillips Deputy Administrator 1951).

Death statistics for the relatively few Europeans in the devastated area emerged quickly, as seen, for example, in a rough, undated, initial listing of 35 'missing' people that is preserved in the archived papers of Ivan Champion (Anonymous n.d.). All of the 28 Europeans at Higaturu Government Station and the seven at Sangara Mission Station were not only 'missing' but also had perished. Those Europeans at Popondetta, Jegarata, Sangara Plantation, Isivita, Waseta and Awala had survived.

Surviving European women and children in Popondetta were flown to Port Moresby via Lae, many of them departing without their husbands who remained to assist in the Lamington disaster area (Wardrop 1951b). Mrs Cowley was leaving behind her dead husband and son. She became hysterical and had to be sedated by a doctor who had come over on the aircraft (Cowley and Virtue 2015). The European evacuees were held up at Lae airport, at least until Mrs Evelyn Murray, wife of the administrator and president of the Red Cross Division in Port Moresby, contacted Qantas who facilitated their departure to Port Moresby, arriving at $3.30 \mathrm{pm}$. Thirteen distressed women and children were met at Jacksons Airstrip by volunteer lady members of the Australian Red Cross in Port 
Moresby, who arranged refreshments and emergency accommodation and supplies for them (South Pacific Post 1951d). Newspaper reporters in Port Moresby needed to find out more about the disaster, and the European women who arrived in Port Moresby by air on this Monday became the first eyewitnesses of the eruption to report on the disaster and its effects to the general public in both the Territory and in Australia. Mrs Cowley was admitted to hospital.

Administrator Colonel J.K. Murray had left Rabaul by air for Port Moresby at 6.30 am on the Monday and volcanologist Tony Taylor was on board with him (Taylor 1951). They were in-flight over New Britain when they heard about the catastrophe that had taken place at Lamington on the previous day. Their aircraft was diverted to Lae because of the temporary closure of Port Moresby airport, but only after they first had flown close to the disaster area. At Lae airport, Taylor met Mrs Kleckham, who had been evacuated from Popondetta, and she told him something of what had happened in the Mount Lamington area (Taylor 1951).

Murray and Taylor flew on to Popondetta from Lae on a smaller Drover aircraft, arriving later that afternoon. Murray took over from Phillips as administrator and Champion was put in charge of the relief operations. Murray and Taylor flew over much of the disaster area in their slow Drover aircraft and saw the extent of the devastation, including on the south-western side of the mountain, as well as the damage to buildings at Higaturu Station and Sangara Mission (Phillips Deputy Administrator 1951). Thousands of trees had been felled creating a blow-down zone in which the tree trunks pointed generally away from the centre of the volcano. The flight, recalled the pilot, Captain Forgan-Smith, was an emotional one for the administrator who could see for himself the catastrophic impact of the eruption on people and communities-both Papuan and European - in the disaster area (Sinclair 1986).

That night, the administrator sent an international telegram from Popondetta to the Department of External Territories, Canberra, and hence to Minister Spender:

HAVE FLOWN OVER HIGATURU WHICH HAS BEEN FLATTENED BY BLAST INCLUDING MOST BUILDINGS AND TREES. RESCUE ARRANGEMENTS IN HAND WITH IVAN CHAMPION IN CHARGE AND ADEQUATE STAFF. CASUALTIES EUROPEAN AND NATIVE UNCERTAIN BUT CONSIDERABLE. VULCANOLOGIST TAYLOR IN 


\begin{abstract}
AREA. INTENDS [sic] STAYING HERE MYSELF. FURTHER EVACUATION ARRANGEMENTS BY SEA ROAD AND AIR IN HAND AND ON VULCANOLOGISTS ADVICE HAVE ORDERED EVACUATION UNESSENTIAL PERSONNEL FROM AREA TWICE THAT HAVING RADIUS KNOWN PRESENT. (Murray Administrator 1951a, 1)
\end{abstract}

This message to Canberra was the first of many that would be made by telephone and telegram in succeeding days and involving, particularly, exchanges between senior bureaucrats S.A. 'Steve' Lonergan, the Territory's acting government secretary in Port Moresby, and J.R. 'Reg' Halligan, secretary of the Department of External Territories and his staff in Canberra. Media releases were written by the department, thus making news of the eruption and disaster a major item in Australian newspapers and radio stations.

The radius of the closed area mentioned in the administrator's telegram was 16 miles. This represents a large area, meaning that Murray and Taylor were taking few chances at this stage. No records are available of the scientific discussions that were held that day between the administrator and the volcanologist, but Taylor, in his reports after the early aerial inspections that day, almost immediately began using the term 'peléean' for the type of eruption that had caused the Lamington catastrophe. Mont Pelée on Martinique Island in the Caribbean had caused similar devastation on 8 May 1902, which was only one day after Soufrière volcano on the neighbouring island of St Vincent, about 150 kilometres away, had produced a similar volcanic eruption. Did this mean that other volcanoes in Papua - and indeed elsewhere in the whole Territorywould join Lamington in eruption? Victory volcano to the east was one potential candidate, and the administrator that evening sent a warning radiogram from Popondetta to district headquarters at Tufi on the Cape Nelson peninsula:

DISCOM TUFI SHOULD YOU RECEIVE THE WARNING OF FARELY [sic] CONTINUOUS EARTH TREMOURERS [sic] IT MAY BE ADVISABLE TO EVACUATE YOUR AREA ESPECIALLY THE AREA AROUND MT VICTORY ADVISE GOVSEC AND DISCOM LAE IF TREMOURS [sic] EXPERIENCED ADMINISTRATOR. (Administrator 1951). 


\section{Tuesday 23 January: Burying the Dead Begins}

Official and volunteer members of the Red Cross Society's Division in Port Moresby, chaired by John H. Ahearn, had been having a busy past 24 hours - and on two main fronts. First, the stressed if not traumatised European evacuees from Popondetta were being looked after by the volunteers, coordinated by Mrs Reita M. Wardrop, general secretary of the local division. The evacuees were provided with clothing and toiletries from local stores, assisted in making contact with relatives in Australia and helped with making travel arrangements to addresses in Australia (Wardrop 1951b).

Second, the local Red Cross officials responded to the urgent need for additional supplies of blood plasma for the burn victims, and particularly for those casualties at Lae Hospital and at Popondetta where there were still injuries to be treated. The Red Cross officials in Port Moresby had contacted Dr Eric Shaw, director of the Queensland Red Cross Blood Transfusion Service in Brisbane, late on Monday afternoon (Wardrop 1951b; Cannon 1951). Shaw promptly made a call for blood donors, arranged for the urgent delivery of blood plasma from both Brisbane and Townsville to the Territory, and 'a dramatic dash was made by plane with 90 litres of serum [plasma] at 1.15 am today [Tuesday]', reported Red Cross headquarters in Melbourne in a press release (Australian Red Cross Society 1951). Fifty 'giving sets' (Wardrop 1951b, 2; Cannon 1951) were also provided. Gunther later wrote:

Our technique at the Popondetta evacuation casualty station was to give plasma without thought to dressings then simply to dress them for their evacuation by air when their general condition allowed. Plasma was not then given en route but immediately to those requiring it at Lae or Port Moresby [hospitals] on admission.

The total number of patients treated will never be known as reports went by the board as our and Mission casualty clearing stations met the first impact. Seventy burnt patients were evacuated by air to Lae and Port Moresby Hospitals with three deaths only. (Gunther 1951b, 1) 
Dr Gunther also expressed his personal appreciation to Dr Shaw and the blood donors:

You should not need to be told that your plasma was life saving ... From our own stores we were able to use plasma on our arrival [Monday], then your supplies arrived as we ran out. This was a tremendous relief as we had had to start to ration by clinical selection, an extremely difficult responsibility in such a rush emergency.

If there is any way you can publicly thank the people of Queensland for me who so quickly rallied to your call to meet our tragedy I would appreciate it ... there need be no doubt their blood really saved lives as the result of one of the worst holocausts of our time. (Gunther 1951b, 1)

The number of injured was, in fact, relatively small compared to the much greater number of people killed by the eruption, and the medical team at Popondetta would have relatively little work to do after the first day or two and particularly after the injured requiring hospital attention had been flown out to Lae and Port Moresby. Further supplies of plasma were not needed, and some plasma was returned to Australia.

Tony Taylor undertook two aerial inspections from an Auster aircraft piloted by J. Arthur, director of the Department of Civil Aviation, on this Tuesday (Taylor 1951). They were accompanied by Fred Kleckham, who was included also in aerial inspections on the following day, because of his knowledge of the geography of the Lamington area. Taylor and aircraft pilots would subsequently make many potentially hazardous flights over the crater area, which were clearly necessary to observe any important changes to the state of the volcano, weather and visibility permitting. Later that day, Taylor collected volcanic samples from the SangaraHigaturu area, which were shipped for scientific examination to his superior Dr N.H. 'Doc' Fisher, chief geologist of the Bureau of Mineral Resources, Geology and Geophysics (BMR) in Canberra. This was just the beginning of a scientific assessment of the eruptions by Taylor and colleagues that would last discontinuously for two years (Taylor 1958). Taylor would be assisted in fieldwork for much of this time by Leslie Topue, a Tolai man from East New Britain who was a volcanological assistant employed at the observatory in Rabaul. However, an urgent requirement for administration staff was not 'science' but, rather, access to Higaturu Station and Sangara Mission. 
Duties this day were prioritised for the new relief and rescue workers. Ivan Champion directed Patrol Officer Des Martin and a team of Papua New Guinean police early on Tuesday to clear the road into Higaturu to retrieve moneys and documents in the safe at administration headquarters using spare keys that had been brought over from Port Moresby. The sight of the volcanic destruction astounded and horrified these first people who tried to negotiate the side road that climbed through the devastated area southwards to Higaturu-Sangara from the arterial Popondetta-Kokoda road. The destruction seemed complete-as if a bomb had exploded, blasting everything away. Vegetation had been stripped, trees felled and remnant trunks split and abraded. Most buildings had been obliterated. Ash covered everything, creating a bleak and monotonous 'moonscape'. Most horrifying of all were the burnt human corpses, including hundreds littered along the access road itself, the fleeing people apparently having been felled as they attempted their escape (Figure 5.2). Martin and the police tried to move to one side the bodies that lay in the road, but the scale of the task, including burial of the already rapidly decomposing bodies, was overwhelming and the actual work seemingly futile. Martin reported the situation back to Ivan Champion and, years later, wrote:

Thousands of rotting corpses were scattered throughout the [devastated] area mostly covered in ash. Many hundreds more were spread out along the road from Higaturu where they had been attending church services on the Sunday morning ... Large numbers of the bodies had split open with intestines spilling out. The stench was appalling ...

Initially we tried to shovel bodies off the road into drainage ditches with four of us working together using shovels to do so. The masses of bodies along the road actually made it difficult to move around without stepping on one. In those days the native police had bare feet and what with ruptured bodies and exuding body fluids the police were slipping and sliding about ... In retrospect it really was the stuff of nightmares. (Martin 2013, 44) 


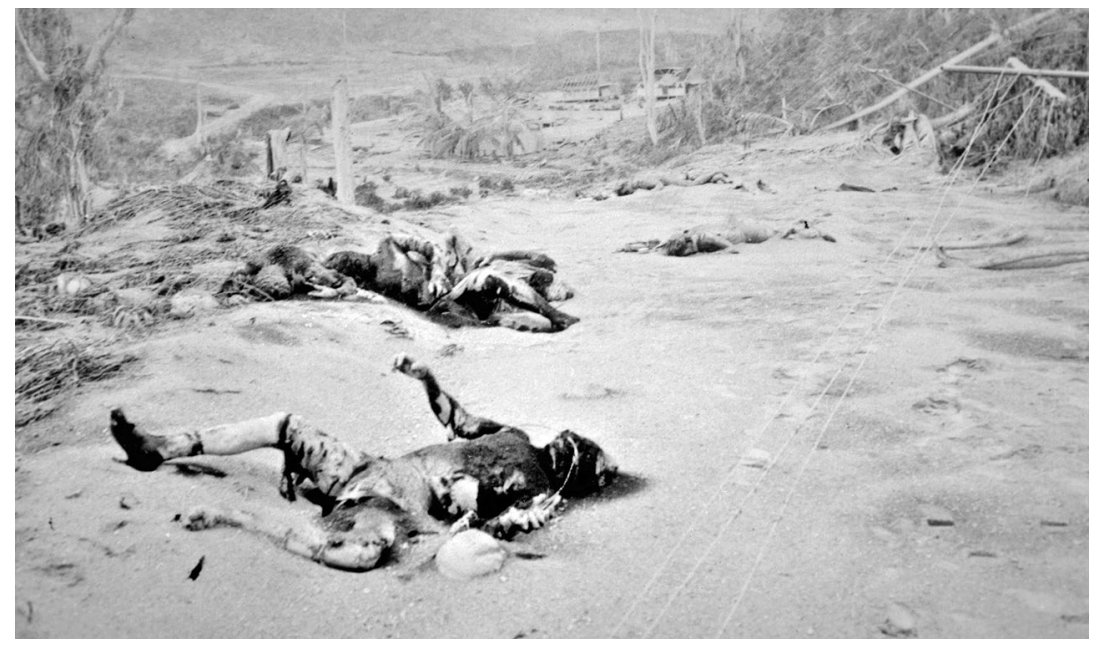

Figure 5.2. Casualties on the Higaturu access road

Casualties on the Higaturu access road are seen in this photograph taken on Tuesday 23 January, two days after the catastrophic Sunday eruption (Taylor 1958, fig. 76). Photograph supplied courtesy of Geoscience Australia (negative number M/1745).

Two other senior administration officers who had arrived at Popondetta were Acting Government Secretary Claude Champion, brother of Ivan and Allan, and Acting Assistant District Officer D. Clifton-Bassett (Murray Administrator 1951k). They led a party of police, labourers and others on foot by the road across the Ambogo River into both Higaturu Station and Sangara Mission. The visit was a short one, however, for fear of further volcanic eruptions taking place. Champion, on the following day, 24 January, and after his return to Port Moresby, dictated a moving report that was telephoned through to Canberra that afternoon:

After reaching Higaturu we made a detailed survey, [but] were unable to move collapsed buildings. Several Europeans and natives were found in vicinity of the District Commissioner's residence-highly decomposed condition. It was difficult to distinguish between Europeans and natives as most of the clothing was apparently blown off. Without question, we have definitely identified C. Cowley who was sitting in his land rover. Mr. Williams, Works and Housing, Mr. Cook, Works and Housing, a European woman not yet identified but believed to be Mrs. Lock ... Three other European males not yet identified were also found. One is believed to be [Erl] Cowley, another Stewart or Humphries. Dr and Mrs Martin and child were found near jeep apparently endeavouring to escape from their house. Works and Housing jeep was found suspended ten feet from the ground on a tree stump. (C. Champion 1951, 1; see Figure 5.3) 


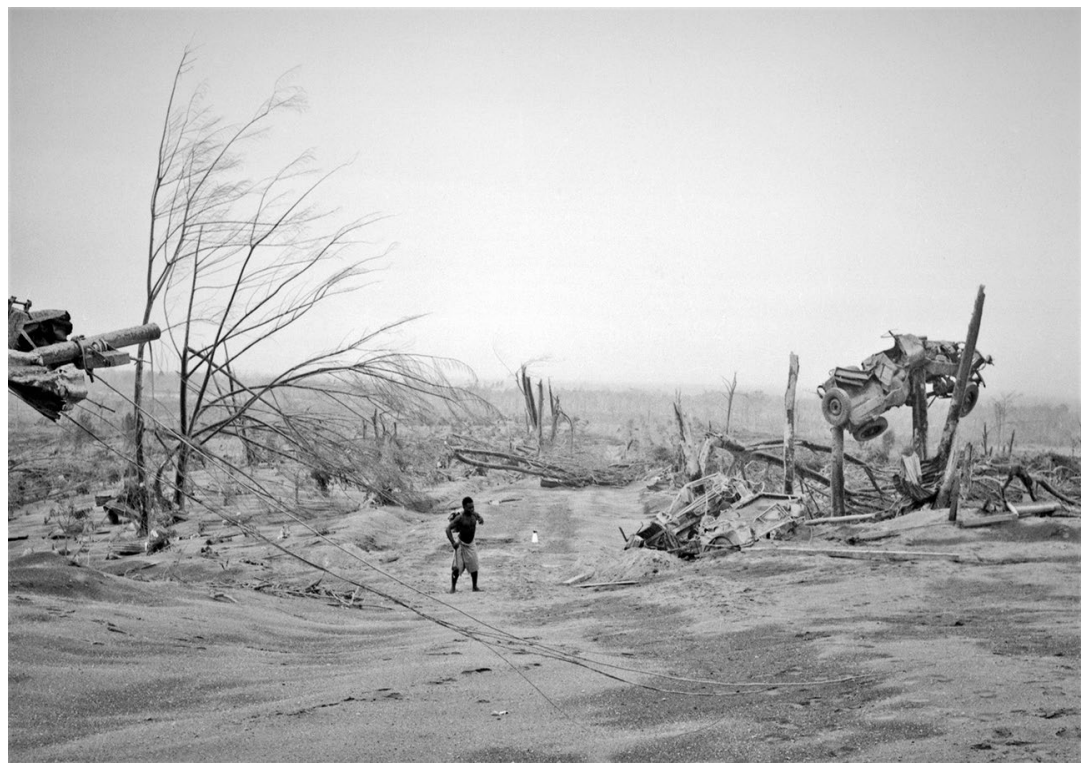

Figure 5.3. Devastated area at Higaturu including destroyed jeeps

Two destroyed jeeps at Higaturu are seen in the devastated area of Mount Lamington (Taylor 1958, fig. 69). The pyroclastic flow ran from left to right. Leslie Topue is in the centre of the photograph. Photograph supplied courtesy of Geoscience Australia (negative number GB/1060).

Claude Champion concluded from the disposition of the bodies at Higaturu that people must have had a few minutes of warning as most in the vicinity of the district commissioner's residence seemed to have been trying to escape northwards down towards the Ambogo River. A survey of the damaged buildings was made, most of which had been flattened. They were unable in the time available to lift the ruins to determine whether there were any bodies underneath them. Champion noted, however, that there was no 'stench' near the buildings. He estimated, further, that '400 natives perished at Higaturu Station alone', and that all 'Europeans and natives found on Higaturu Station were buried' (C. Champion 1951, 1).

What the Champion party saw at Sangara Mission was no less distressing:

The road was strewn with dead natives. In Reverend Taylor's house which was still standing we found one of their children aged 4 or 5 . The Taylor child was easily recognisable and was not burned at all. About 200 yards further through the Mission Station the body of Miss De Bibra who was fully clothed even to shoes was 
found. She was apparently killed by blast as she did not appear otherwise injured and was not burned. Those bodies were buried at Sangara. (Champion. C. 1951, 1)

They next made a search of the mission's coffee plantations, which was where Reverend Taylor, before he died overnight at Popondetta, had said he had left his wife and two children hiding behind a tree stump. Many bodies were found in this area but identifying the victims was difficult:

We then passed through Sangara Village ... Dead natives were strewn everywhere ... The whole area was a scene of utter desolation and it would be impossible for any one to still be alive in the area covered by the party. It is intended to clear the road leading to [Higaturu] to enable trucks to get by with large search parties in an endeavour to find more bodies ...

The burial on the roadside is a major task as we saw approximately 400 on the roadway to [Higaturu] ... There are at least 9 villages whose inhabitants were completely obliterated and many more dead from burns. It will be some time before a reasonably accurate death toll can be given. At the moment it is estimated that there are 4000 dead and injured. The biggest proportion being dead. (C. Champion 1951, 1-2)

Claude Champion's official field party had demonstrated clearly the scale of the disaster management tasks ahead. Champion's figure of 4,000 dead and injured would later be used commonly in newspapers and reports as the actual death toll for the Lamington disaster, and this statistic became well distributed before a more accurate, but less publicised, estimate could be made when opportunity allowed in later weeks.

Anglicans Reverend W.E. Moren and Paul Rautamara flew to Popondetta on 23 January from Lae. They accompanied the Champion party into Higaturu Station and Sangara Mission, and undertook Christian burial services there (Murray Administrator 1951b; Strong 1951; Rautamara 1951). Reverend Moren thought that other Anglican priests in the area may not have been able to attend to such services as quickly as he could by flying in from Lae, but he found that Reverend John Anderson had already arrived in the disaster area. Moren returned to Lae on a flight that same day. Peter Rautamara described finding and burying recognisable bodies at Higaturu and Sangara Mission, including those of his brother Reverend John Rautamaru and family members: 
About 12 yards along the path that leads from the mission house to the vestry I found Mona, John's wife, and Cecil Marua's wife, Maud. Alongside the rubber trees nearby my brother John's life had ended. Dulcie, his daughter, lay at his head and I was glad that I was there to represent the Anglican mission as a witness. Weeping I took a spade and buried the bodies and Fr. Moren said the prayers (Rautamara 1951, 9)

Many hundreds of corpses had to be buried before the tropical climate caused any further deterioration of the cadavers thus creating a health risk, and to avoid as much as possible the scavenging of bodies by pigs, dogs and poultry. Identifying the European victims from their remains was also important, but difficult, for the administration so that the Australian Government in Canberra and the victim's next of kin could be advised. That same attention was not, and could not, be given to the thousands of dead Papuans. Champion had already alluded to difficulties in body identification, especially where clothes had been blown off, and the skin colour of the burnt corpses could not always be determined. Taylor $(1958,49)$ thought this 'may have been partly due to an intense post-mortem lividity which is characteristic of deaths from asphyxia'.

Judge Phillips flew out of Popondetta on Tuesday morning and returned to Port Moresby. Professional volcanological advice was now being given directly to the administrator in the Lamington area by volcanologist Tony Taylor, but the deputy administrator, in a telegram to Canberra that evening, offered some further volcanological opinion and observations on the basis of his Rabaul volcano experience in 1937. He noted first that the:

Great field of pumice [on the slopes] was scored very freely by what seemed to be many water courses possibly made by heavy rain or by sudden cloud burst due to condensation of vapour column as happened in Rabaul in $1937 .$. [and, second, that] ... the pumice that had banked up around the core of the volcano ... might tend to act as a stopper which volcano forces may yet attempt to remove. (Phillips Deputy Administrator 1951, 4-5)

The kiap at Kokoda, Acting Assistant District Officer 'Bunny' Yeoman, first visited the disaster area on this Tuesday when there was 'No disturbance of Lamington apparent' (Yeoman 1951, 2). Mrs Searle was surprised to see Yeoman when he arrived at Waseta: 
Why had Bunny walked here NOW, for what reason? Bunny had come to take us OUT of the area, and up to Kokoda. From the beginning I had felt his unease at coming into an area where everywhere was thick with volcanic ash and debris. (Searle 1995, 248)

Mrs Searle and the three children packed their bags for their hike with Yeoman and a line of carriers to the Kumusi River, crossing it at Wairopi by the narrow, timber-floored swinging foot bridge, and up to the government rest house where they stayed the night. Yeoman was anxious to start again in the morning, however, so the group was up by $5.00 \mathrm{am}$ and they resumed their relentless trek to Kokoda. Eventually, they met a truck coming down the road, which turned around and took them all back to Kokoda. Mrs Searle's husband, Clen, stayed behind at Waseta and Awala to assist with rescue and response efforts. Anthropologist Marie Reay left Waseta later than the Searle-Yeoman group, but she too had reached Kokoda by Wednesday (Anonymous 1951a). The European women and children all flew to Port Moresby on the Thursday, where Mary Rose was finally reunited with her anxious parents (Searle 1995). These arrivals at Jacksons Airstrip were filmed, and the Searles and Marie Reay were shown in a newsreel entitled 'New Guinea: The Haunted Mountain in Eruption' (Gaumont British News 1951).

\section{Wednesday 24 January: Media, Support from Australia and Ecumenism}

Claude Champion returned to Port Moresby on 24 January. His emotional breakdown was witnessed at Jacksons Airfield and later reported in newspapers, but Champion soon focused on providing a dictated report that was sent to the Department of External Territories in Canberra by radiophone (C. Champion 1951). Press journalists and photographers from Australia had arrived in Port Moresby and Lae from Tuesday onwards 'in greater numbers than at any time since the war', the first representatives being from the Brisbane Courier Mail (South Pacific Post 1951c, 3). Reporters from the Sydney Daily Telegraph, however, were quick to charter an aircraft on Wednesday and were able to return photographs to Sydney in time for publication on Thursday. Other journalists arrived from Manus Island where they had been covering war crime trials. Most of the journalists made their headquarters in Lae where they had easier access to the disaster area at Mount Lamington. 
An informed Australian Government back in Canberra had already been active in arranging to send two Dakota C47 aircraft from the Royal Australian Air Force (RAAF) to the Territory in support of the relief effort by air (Bullard 2017; see also Sinclair 1986). Dakotas were the main transport aircraft for the RAAF during World War II (WWII). They had a payload of 3,400 kilograms and a capacity for airdropping supplies and so were well suited to the task of supplying the growing refugee camp at Wairopi where there was no nearby airstrip. The first Dakota had departed from Australia on the previous day, 23 January, carrying dropping-parachutes, water containers and blood plasma provided by the Australian Red Cross (Bullard 2017). The second aircraft left the next day. These departures were the beginning of what would become weeks of similar RAAF support for the administration and Lamington evacuees (Figure 5.4). Qantas aircraft also participated in dropping operations (e.g. Civil Aviation 1951). The Australian Red Cross, both in Port Moresby and in Australia, played an important backup role to the administration during the relief phase at Mount Lamington but much less so in the disaster area itself (Wardrop 1951b; Ahearn 1951a, 1951b; Australian Red Cross Society 1951; South Pacific Post 1951d; Bullard 2017).

Administrator Murray that evening sent a comprehensive telegram from Popondetta to the minister in Canberra reporting on events and progress (Murray Administrator 1951c). He had visited Higaturu Station himself during the day, together with Dr Gunther and Ivan Champion, and thought that as many as 700 bodies had been buried that day (Murray Administrator 1951k). Normal burials were not feasible in the conditions they faced and bodies were being interred by heaping pumice over them ... The dead must be interred where they lie ... Stoic fortitude patience and smiles of the treated dying will live in memory' (Murray Administrator 1951c, 1-2). Body identification remained a problem. Murray was complimentary of all those who were involved with the relief effort, mentioning notably that the missionaries had done 'more than their best'. Eight bulldozers and a tractor had been flown in to improve the airstrip at Popondetta. 


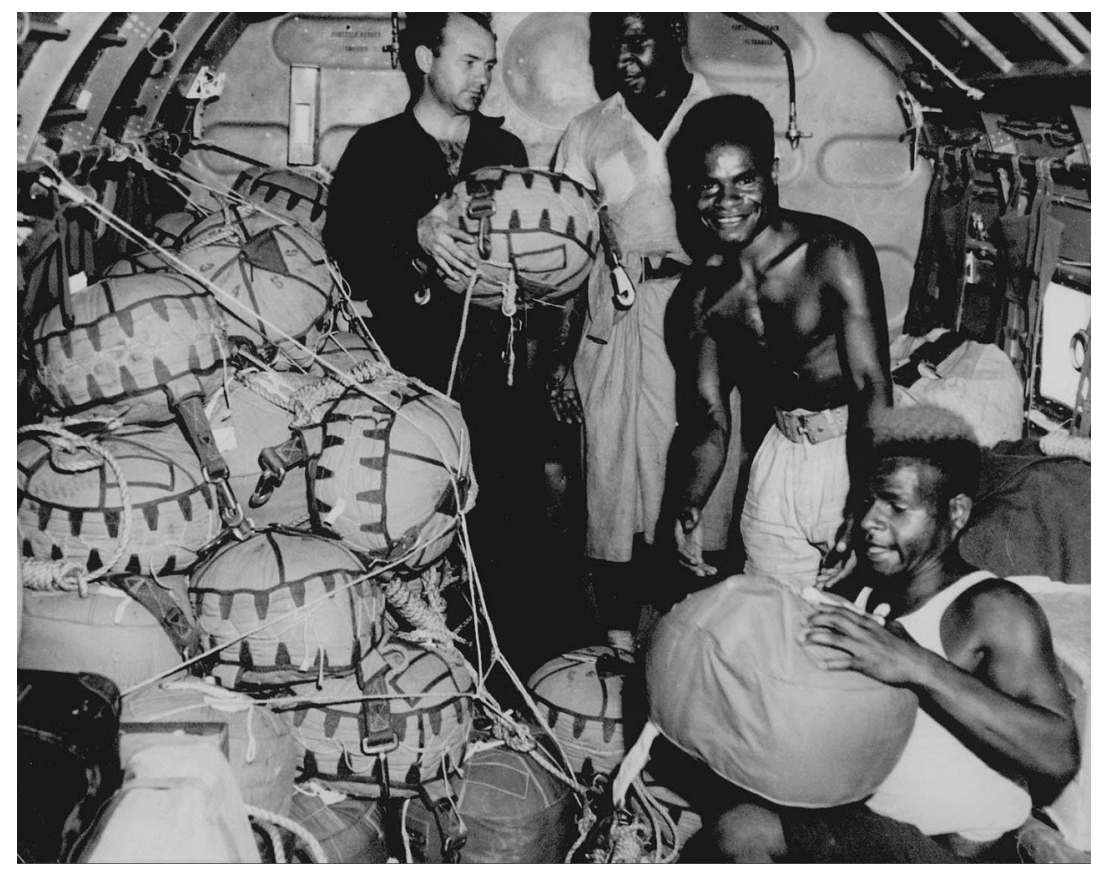

Figure 5.4. Dakota crew preparing to airdrop supplies

A Dakota crew prepares to airdrop supplies for evacuees in the Lamington disaster area. The photographer is unknown, but the photograph appeared on the front page of a Brisbane newspaper on Thursday 25 January 1951 (Courier Mail 1951). This digital copy was provided courtesy of the Kleckham family.

Murray also reported that the whole disaster area had been closed to all except officials and permit carriers, and indeed no further administration parties entered the Higaturu area for another week (Murray Administrator $1951 \mathrm{k})$. This prohibition, however, did not come into effect until two general burial services had been held, overlooking the now devastated Sangara Mission Station and Higaturu Government Station. The first ceremony was led by the Anglican Reverend Anderson and supported by Roman Catholic Father Justin Lockie who had flown in from Lae (Justin 1951; Henderson 2001, 2007). The administrator read a lesson from the Bible. The second service was a requiem mass led by Father Justin who made use of the bonnet of a jeep (Figure 5.5) and who was assisted by Reverend Anderson (Justin 1951). The administrator reported Father Justin's own words that 'calamity leads us ... to realise our oneness' (Murray Administrator 1951c, 2). Sister Henderson recalled the service as 'a wonderful ecumenical moment' (Henderson 2001, 6). 


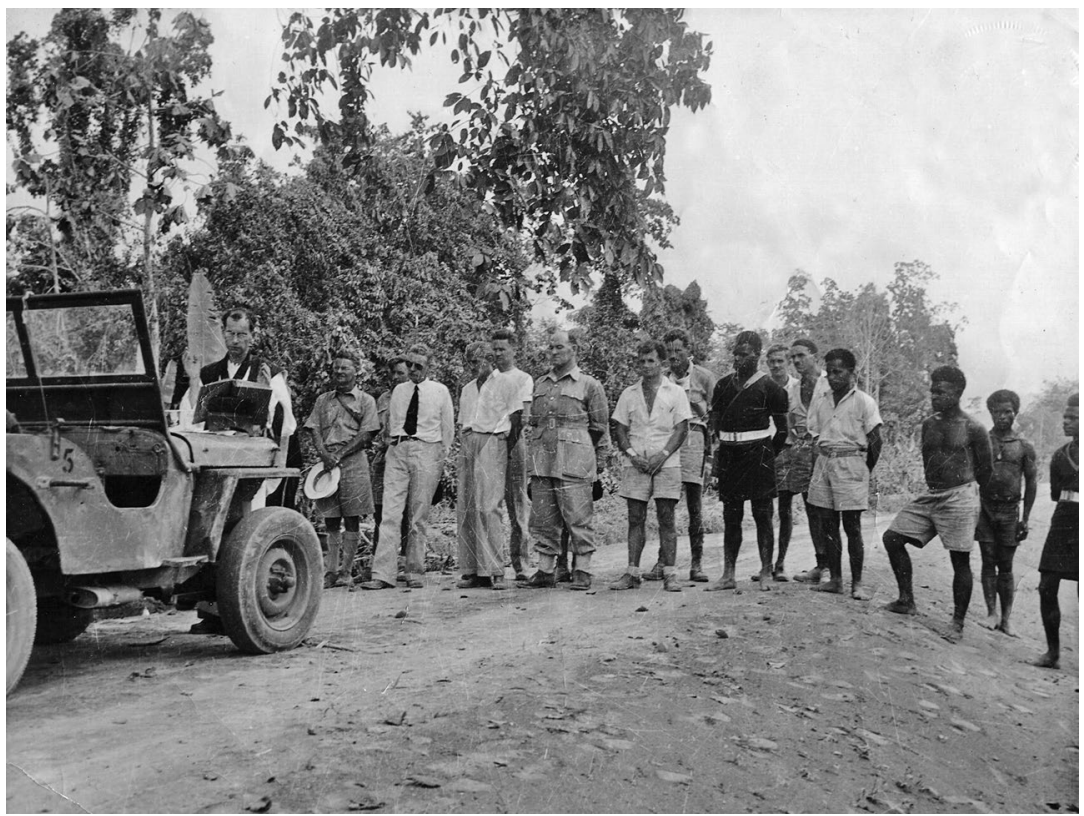

Figure 5.5. Requiem mass held by Father Justin on bonnet of jeep

The requiem mass took place on 24 January 1951 at the edge of the devastated area. Senior administration officers are, from left to right: Ivan Champion, carrying a hat in his hands; Administrator J.K. Murray wearing sunglasses; Dr John Gunther; and the uniformed J.S. Grimshaw, commissioner of police. Patrol Officer Des Martin is in the centre-rear (behind the unidentified European clasping his hands in front) wearing a surgical mask around his neck. Martin had just returned from work in the nearby devastated area and had doused the surgical mask with disinfectant to cope better with the smell of putrefying bodies. His photograph was published in the Sphere magazine of 10 February 1951. The photographer is unknown. This digital copy was provided by D. Martin.

The acting government secretary in Port Moresby, Lonergan, telephoned the Department of External Territories in Canberra at $10.00 \mathrm{pm}$, and the conversation was typed for the record (Anonymous 1951a). Lonergan covered several topics, including the limited success in identifying European bodies, although the body of Erl Cowley, son of the district commissioner, had been found. He noted the successful airlifts that had taken place but also that the arrival of so many aircraft at Popondetta out of Lae had held up aircraft leaving Port Moresby. Nevertheless, the delivered cargo included two jeeps, two lighting sets, fuel for motor vehicles, spares and food stuffs. He said that Mrs Searle, her two children, Mary Rose Henderson and Marie Reay would be flown to Port Moresby the next morning. 
The deputy administrator, Judge Phillips, then came on the telephone to advise that a journalist in Port Moresby was pressing for information to be sent to Australia about the Lamington eruption along the lines that 'the Government had not done enough to foresee this disaster and take steps. Apparently they based this on talk of women who got out from Higaturu one of whom [gave] a talk over 9 PA [the local radio station] the other night' (Anonymous 1951a, 1). Phillips stated that he had agreed to give a press conference on the matter the following day. Further, he had completed that day a formal report for the attention, in due course, of the administrator (see Phillips Deputy Administrator 1951). This report was dispatched to Canberra the following day together with a covering letter from the acting government secretary. The radio broadcasting woman was identified in the letter as Mrs Gwilt whose comments were reported as having been 'rather hysterical'. Mrs Gwilt had said also that there had been earth tremors in the area for six weeks prior to the catastrophic eruption, which 'was certainly news to us as there had been no report from Cec. Cowley of this and I very much doubt that the statement is a rational one' (Acting Government Secretary 1951, 1).

Meanwhile, an issue of a different kind was brewing for Tony Taylor back at Mount Lamington. He had been informed by administration officers in the field that 'further activity was imminent', although the reasons for this volcanic forecast were not recorded (Taylor 1951, 2). An eruption, nevertheless, did take place at 3.00 am the next day, and Taylor immediately advised Ivan Champion that field parties should not enter the area throughout the coming Thursday.

\section{Thursday 25 January: New Eruption, Bishop Strong and Prohibitions}

Mr Lonergan telephoned Canberra in the morning advising the Department of External Territories about the new eruptive activity, together with the related news from Lae that the Department of Civil Aviation had prohibited all aircraft approaching within 50 miles of Mount Lamington (Anonymous 1951b). Aircraft heading for Popondetta, however, could do so by approaching from the north-east over the sea. Lonergan also said that more European bodies had been found, that 520 other bodies had been buried and that: 
Accommodation at Popondetta for Europeans is strained to the utmost, and sight-seers are not permitted to enter ... We have allowed press to go in up to the present and we will as far as possible continue to do this. (Anonymous 1951b, 1)

Dr Gunther had said there was now ample medical aid and that offers from organisations such as the Red Cross were not required at present. The number of evacuees at the Wairopi camp was now about 2,500.

Concerns had emerged that Popondetta, which so far had escaped the worst of the eruption, might not itself be invulnerable to future volcanic activity and that an alternative wartime airstrip may be required. Colonel Murray told news media in Port Moresby that:

We are planning a main operational base at Embi, only 18 miles from Mount Lamington. This will be an ideal spot, as the airstrip there can take big transport planes even in bad weather. With a heavy fall of rain, Popondetta would be out of operation for anything but small aircraft, but it could still be used as an advance base for small planes. (South Pacific Post 1951b, 1)

Embi Lakes are near Inonda where there were evacuees. Tony Taylorafter an aerial inspection of the Lamington crater in the morning-flew over Embi Lakes, which he determined were not directly of volcanic origin and were therefore not a potential threat (Taylor 1951). Four Douglas C-54 'Skymaster' aircraft were able to land at Embi, and both Popondetta and Embi were able to be used during the relief and recovery efforts in the days and weeks ahead.

This Thursday was when Bishop of New Guinea Philip Strong first arrived at Popondetta after sailing from Dogurua to Cape Killerton on the mission boat St George (Strong 1951, 1981). Strong would stay for 10 days and witness firsthand the volcanic devastation in the area, including the destruction of Sangara Mission where there had been so many deaths of the members and missionaries of his own Anglican diocese. The blow must have been severe, coming after the tragedy of the wartime murders and martyrdom of the Anglican missionaries that had resulted from his decision not to evacuate in advance of the Japanese invasion.

Bishop Strong had noted the following in his diary for Sunday 21 January - that is, before he heard about the terrible effects of the catastrophic eruption that day: 
I was oppressed throughout the day with a deep sense of gloom, fears and evil forebodings. Spent most of the morning wrestling in my chapel. Have seldom experienced anything so intense or so terrifying. Felt utterly that I had failed and all kinds of terrible possibilities seemed to brood up before me ... awful depression. (Strong 1981, 212)

The editor of Strong's published diaries noted that they, as a whole:

Make a powerful cumulative impact as they portray in some detail the slow and agonizing process of adapting to the consequences of a belief that missionaries should stay where they were. In short, the 'Call', as he perceived it, had to be worked out regardless of military strategy or the fortunes of great-power politics. (Wetherell, quoted in Strong 1981, x)

On 25 January, the bishop visited great crowds of evacuated people milling around at Cape Killerton, speaking and praying with them, and trying to offer comfort. Reverend John Anderson then took him to Popondetta where he stayed in the house where Dennis Taylor had died. He noted for this day some talk that Popondetta, although still safe, may have to be evacuated and that the administration was considering establishment of a new camp at Embi.

Another telephone call took place between Port Moresby and Canberra that evening, at $9.10 \mathrm{pm}$ (Anonymous 1951c). Lonergan informed Halligan that the road into Higaturu had still not been fully cleared and that Tony Taylor had advised against the entry of burial parties because of concerns about the possible impact of new eruptions at the volcano. Taylor's senior at the BMR in Canberra, Dr N.H. Fisher, an ex-volcanologist with Rabaul experience, had enquired through the Department of External Territories about the work being done by Taylor and had offered to visit the Lamington area himself. The administrator, who, on this day, was back in Port Moresby, said that he was very satisfied with, and confident about, Taylor's ability. However, he would be pleased to have Dr Fisher visit the Territory because the Lamington experience requires examination of the Kokopo-Rapopo site having regard to Toma Mount Varzin' (Anonymous 1951c, 1). Murray was here referring to his involvement in the ongoing issue in East New Britain of transferring the functions of the volcanically vulnerable town of Rabaul to the Kokopo area, and to the fact that Mount Varzin, which is very close to Toma, but less so to Kokopo, was an apparently extinct volcano. 
Lonergan also advised Halligan that a press conference had taken place that afternoon in Port Moresby. This meeting with the press involved the administrator, his deputy, Judge Phillips, and the government secretary. Judge Phillips had read out his report concerning his knowledge of the lead-up to disaster at Mount Lamington. The conference was said by Lonergan to have been 'very amicable and very successful' (Anonymous 1951c, 1). However, questions about the role of the government and of Phillips himself would grow in the days ahead. The members of the press clearly suspected there was an important story to be followed up after the public remarks that had been made by Mrs Gwilt and the other European women.

\section{Friday 26 January: Criticisms and Thoughts about Rabaul}

Details of the relief work undertaken in the Lamington disaster area since Monday dominated the front page of the South Pacific Post (1951b) on this Friday, appearing under the headline 'Plan Ready for Any New Emergency in Our Worst Disaster'. An appreciation was also published of the now deceased District Commissioner Cecil Cowley, which had been written by Sergeant-Major Guise of the Royal Papuan Constabulary who had served under Cowley in 1947. A photograph of the previous Thursday's eruption taken by the late Kevin Woiwod was also published, together with a caption saying that the image had appeared already in national newspapers throughout Australia.

This Friday's issue of the South Pacific Post also contained a letter from E.L. Hand who was highly critical of the reception given to the Popondetta evacuees on Monday 22 January by Port Moresby residents. Hand suggested that, in future, St John's Ambulance staff should form a welcoming committee, thus criticising the Australian Red Cross who, in fact, had provided considerable assistance in Port Moresby. This criticism of the Australian Red Cross was strongly rebutted the following week in a letter signed by eight of the evacuees who warmly praised the Red Cross for their work-namely, Heather Gwilt, Marie Reay, Mary Henderson, Marjorie Kleckham, Pat Searle, J. Boyd and Connie Morris, as well as Maggie Rae whose name should not be confused with that of anthropologist Marie Reay (South Pacific Post 1951c, 8). Further, a Brisbane-based letter writer in the same issue also stressed the role of 
the Red Cross in both Brisbane and Port Moresby in coordinating the provision of blood plasma. Finally, the South Pacific Post itself combated the implied criticism in an extended article entitled 'Red Cross Was Ready for Action' (South Pacific Post 1951d, 8; see also correspondence on files of the Australian Red Cross Society 1951).

Taylor at Lamington saw marked changes to the crater area as a result of a morning aerial inspection on this Friday (Taylor 1951). He had been tracing previous changes over the past few days, which would become even more marked over the coming weekend and into the following week. Taylor attempted to reach Isivita villages on foot to check seismic activity there, but failed owing to mudflows in the Ambogo River. Seismic data were recorded by him 'by improvised methods' throughout the night at Sangara Plantation, but there is no record of exactly what those methods were (Taylor 1951, 2). Taylor had no seismograph at this time, but he had a particular interest in observing whether some kinds of seismic signal preceded identifiable types of eruptive activity. Other people who were there would relate, and not apocryphally, how Taylor would lie on the floor flat on his back to best 'feel' ground shakes, and to observe the seismically induced ripples on the surface of a glass of water (e.g. Blaikie 2006).

Steve Lonergan in Port Moresby and Reg Halligan in Canberra had a further telephone conversation on what was the last day of the public service working week in both capitals. Halligan referred to an article in the Canberra Times that morning containing information that was said to have come from Port Moresby:

Authorities have again refused to issue the names of the European dead found today [25 January]. They are having difficulty in identifying such bodies and will leave it to Canberra to announce the names after next of kin have been notified. (Anonymous 1951d)

The newspaper headline read ' 34 Europeans dead-20 bodies recovered'. The two bureaucrats then compared their respective lists of European casualties and concluded that 11 of 14 bodies had been identified, meaning that, at this particular time, as many as 24 out of a total of 35 were still unaccounted for. Identifying the dead and informing next of kin would continue for many months, as would any final estimation of the very many more Papuans who had lost their lives. 
Mr Lonergan also reported that Assistant District Officer Holmes had inspected 15 villages south of Inonda down the eastern side of Mount Lamington. Among these would have been the two Anglican mission stations of Sewa and Sehaparete that Margaret de Bibra mentioned in her letter of 21 January (Figure 4.6). Sehaparete Mission was within the zone of complete destruction. Nearby Sewa was beyond it and had escaped the pyroclastic flows. About 100 survivors were evacuated from affected villages, but there were many more fatalities. Ivan Champion had reported that 'Holmes did [a] magnificent job and buried several hundred dead he found' (Anonymous 1951d, 2). A base would be established at Embi and three aircraft were flying to Popondetta and Embi that morning. Two RAAF aircraft were still in use, and the population at Wairopi had grown to 3,500. Lonergan also wrote to Champion saying that he:

Should give consideration to relieving the pressure on some of your chaps, even if only temporarily, and I do suggest that as soon as possible you should yourself come to Moresby for 24 hours to be spent in bed. Good luck to you, you are doing a grand job. (Lonergan 1951b)

The administrator considered that, as a result of the Lamington disaster, the move from Rabaul must be regarded as an urgent matter. Dr Fisher had advised that a Lamington-type eruption was unlikely at Rabaul, but there was no need for concern about the Toma-Mount Varzin area as the active volcanoes were all inside the caldera harbour at Rabaul (Territories 1951).

Dr John Gunther, director of public health, was back in Port Moresby on Friday 26 January where he wrote a comprehensive account of his visit. He noted the health challenges ahead, and pointedly placed the Orokaiva catastrophe, whose effects he had witnessed, in its doubleimpact, historical context:

Our problem remains to protect from epidemic disease some 8,000 people who are refugees from their homes and who in the short space of eight years have now twice seen their villages destroyed [-i.e.] by the explosion of war and the explosion of Nature. (Gunther 1951b, 5)

The two 'explosions' were also in the context of adaptation to almost 50 years of Australian colonialism, during which time traditional ways had had to change and adapt to, and equilibrate with, the ways of an outside world that clearly would not be disappearing any time soon. 


\section{Saturday 27 January: Aerial Inspections and 'Secondary' Explosions}

Taylor made three flights in a Dragon aircraft on 27 January to check on the crater again, but also to investigate reports of new eruptive vents having formed on the mountain. Such a report had been received the previous day and the alleged vent had been examined from the air. Taylor concluded, however, that these 'vents' were 'secondary ash bed phenomenon' (Taylor 1951, 2). Hot, wet masses of recently deposited ash were exploding as a result of internal water vapour pressure building up and then being released explosively, giving the impression of a new vent. Taylor also noted a 'very encouraging correlation of seismic activity and eruption [was] established by observations at Popondetta during the night' (2).

Bishop Strong said mass in his house that day, John Anderson having prepared the altar, and attendance of the service included Rodd Hart and some local people (Strong 1981). Strong marvelled that Rodd and Madeleine Hart's lives had been spared owing to them being at Jegarata on their honeymoon rather than at Sangara Mission. He also wrote a confidential letter to the administrator, but its contents are not included in the published version of his diaries.

\section{Sunday 28 January: One Week Later}

Tony Taylor undertook another aerial inspection in the morning. He noted later that:

Vigorous activity had begun at 0600 hours and continued until heavy cloud prevented further observations. At 1100 hours the Administrator and a party entered the area with the intention of proceeding to Higaturu. His Honour and party were advised against proceeding further. (Taylor 1951, 2)

Patrol Officer Bob Blaikie was at Popondetta later that morning when:

A ragged, dirty and quite exhausted Bill Schleusener staggered into our forward base. He had walked alone for a week searching for and burying the dead and assisting the living ... Dr Svirklys [Sverklys] quickly had Bill on to the operating table as it was feared that his lungs were clogged with pumice dust and ash ... [Pilot John 
Arthur, together with Tony Taylor on board, and after returning to Popondetta from the aerial inspection,] flew his aircraft extremely low over the house revving his engine up and down warning us of a further eruption ... At just after midday Mt Lamington again erupted with multiple explosive outbursts ... Then suddenly, like Lazarus arising from the dead, Bill leapt up from the operating table shouting something to the effect that 'It nearly got me the first time but it won't get me again'. (Blaikie 2006, 38)

Schleusener raced outside but was persuaded to return by Patrol Officer Blaikie. Events of a quite different kind meanwhile were taking place that day at Gona.

First, Bishop Strong celebrated the morning service in the Holy Cross Church at Gona: 'A great mass of people present. Quite a thousand, overflowing the church and joining in the service from outside' (Strong 1981, 214-15). Then, in the afternoon, and to Strong's 'surprise and joy', Bishop David Hand arrived. Hand had heard about the eruption and disaster while in Australia, and had been asked by Strong to return, as he explained in a mission publication:

I am going back in response to a message from my superior officer, Bishop Philip Strong. I am not sorry that this is the order, because knowing that district as I do and being the only European who knows the language and the native people of that district, I feel that I may have something to offer in assistance in the rehabilitation and helping of these sadly smitten people. (Hand 1951, 21)

Hand's arrival was a 'great relief' to Strong who eventually handed over to him mission responsibilities in the disaster area after a stay of 10 days so that he could return to duties at Dogura and elsewhere in the diocese (Strong 1951, 50).

Strong (1981) wrote in his diary for this day words that would be shared later with Anglicans in Australia through a national Anglican publication (Strong 1951). The bishop provided a mystical and religious response to what he had been experiencing in the Lamington disaster area:

God has taken into the eternal sphere of His Kingdom not only the members of His Church at Sangara, but their priests, their missionaries and their teachers as well ... We must not grieve for the dead. They are in God's keeping. Indeed we can rejoice for them and give thanks, for with very many of them their call came to them on the LORD'S OWN DAY [Sunday] ... What a blessed 
viaticum! [i.e. the Holy Eucharist offered as last rites before death] $\ldots$ and as we remember the suddenness of the call that came to so many of our dear ones that Sunday morning, we must let the volcano be a Voice calling us to live our lives day by day so near to God that we may be ever ready to meet Him beyond the veil of death. (Strong 1951, 50)

The role of God-in particular his wrath-in explaining the cause of the disaster would be taken up by others who were less celebratory of the spiritual meaning of the eruption and its effects on the lives of so many people.

\section{Monday 29 January: Re-establishing Mission Work}

Bishop Strong heard that the administrator, Colonel Murray, was planning to enter the Sangara Mission area on Monday 29 January. The bishop joined Murray in the hope of being able to find the bodies of Mrs Taylor and her children; to identify and give Christian burial to the bodies of mission teachers, if they could be found; and to retrieve any station records. The group reached as far as Sangara Rubber Plantation and some of the devastated villages where there was a:

Terrible sight indeed with dead bodies still lying about. Complete and utter desolation. Not a speck of green or a blade of grass anywhere ... The Administrator said that no scene that he had witnessed in either of the two wars was so terrible. (Strong 1981, 215)

The group could see across to the Sangara Mission Station, but Tony Taylor had come along with the party and he turned them back saying 'he could not permit anyone to go in, as he considered another explosion might be imminent' (Strong 1951, 49).

Bishop Strong and Colonel Murray that afternoon travelled down to the north coast to visit the evacuees at Cape Killerton as the administrator was anxious to see the situation there for himself. They later sailed round to Gona on the mission boat St George and both knelt by the side of the grave of Reverend Dennis Taylor who had been buried at the foot of the mission cross, which still bore the marks of Japanese bullet impacts (Murray Administrator 1951d; Strong 1951; Tomkins and Hughes 1969; 
Strong 1981). Mission losses, both Papuan and European, were great: Dennis Taylor and all of his family, many hundreds of baptised church members, the Reverend John Rautamara, 18 Papuan teachers who were at Miss de Bibra's training course and Miss Peggy De Bibra.

The bishop had already spoken to the administrator and had received his agreement about the opening of mission schools at Wairopi, which was now the largest of the evacuation camps, holding about 4,000 people. Ivan Champion had suggested that the mission's existing outstation of Eiwo, which was close to Wairopi, would be the best place for schools, and the Harts had expressed their willingness to go there (Strong 1951, 1981). They, together with Albert Rarika, George Ambo and other mission teachers, all of whom had survived the tragedy, flew out of Popondetta to Kokoda and hence to Wairopi and Eiwa, joining Father Porter in this restoration of the mission's work in the area. The bishop visited them all during the week before his departure, noting that 1,000 people had gathered for Evensong in the open air on the night he was there.

Colonel Murray in the evening sent another telegram to the Department of External Territories reporting on the day's events (Murray Administrator 1951d). He added that the road into Higaturu still had to be cleared, but that surviving government documents, as well as some private belongings, had been retrieved from what remained of the government station. Vaccinations against whooping cough were progressing well among the refugees in the camps. The challenge of water supply was being handled resolutely, but there were still problems of hygiene and sanitation. He advised, too, that the evacuation camp at Oro Bay was much better than the one at Cape Killerton, which he would be closing (Murray Administrator 1951d). One disadvantage of Cape Killerton was that it backed on to swamps, so diseases such as malaria were a threat. Further, the mountain Orokaiva in these camps were now in 'enemy' Yega territory, were apprehensive about the sea and had regard to the threat of tsunamis.

A canteen run by the Red Cross in Port Moresby began operating at Jacksons Airstrip on this day 'to provide morning and afternoon tea and lunch for the crews of relief planes, ground staff and members of the Administration, particularly Native Services' (Rooney 1951, 1; see also Wardrop 1951b; Australian Red Cross Society 1951). This service was provided until Thursday 15 February, but was not required at weekends. 'Biscuits, cheese, fruit honey and jam were placed on the tables before morning tea for it was found that some members of the crew preferred these things before undertaking a flight', reported organiser Petrea Rooney $(1951,1)$. 


\section{Tuesday 30 January: Changing Responsibilities and Research Directions}

The volcano was more active in the morning of 30 January, starting at $5.00 \mathrm{am}$, although debris fallout appeared to be confined to the general area of the crater, reported the administrator at 8.00 am (Murray Administrator 1951e). Colonel Murray also advised that he had asked Tony Taylor to report directly to the Department of External Territories in Canberra rather than through him.

The administration in Port Moresby at 9.45 am sent the department an update about the ongoing volcanic activity, adding that 20 days of supplies would be delivered at Wairopi by RAAF airdrop on the following day, Wednesday (Administration 1951b). They mentioned too that anthropologist Marie Reay would be relocating her research work to New Ireland. She did not return to the Northern Division.

A report dated 29 January appeared in an Australian newspaper on 30 January stating that the looting of European houses had been taking place at Higaturu, which was within the area still regarded as volcanically dangerous (Sun 1951). Police had been 'risking their lives rounding up looters'. However, further looting does not seem to have been a problem in the disaster area.

\section{Wednesday 31 January: Rehabilitation and Instrumental Monitoring}

By the end of January, serious attention was being paid by senior administration officers to a reorganisation of the Northern Division and to rehabilitation of people displaced by the eruption of 21 January. These officers included the government secretary and director of the Department of Agriculture, Stock and Fisheries (DASF) (Dwyer 1951) — both in Port Moresby-and Ivan Champion at Popondetta (Rich 1951). The challenges were listed in a memorandum, apparently from the government secretary to the administrator, highlighting:

Preparation of a plan with consideration of a number of major points particularly decisions as to a new HQ for the Division; appointment of a District Commissioner; compensation; repatriation of time expired labourers; acquisition of land for resettlement purposes; establishment of an administrative rehabilitation group; 
production of foodstuffs; transportation; possibly resubdivision of the Division; establishment of a special subdivision to include selected resettlement areas the administration of which would be a dual concern of the HQs of the Administration and the District Commissioner selected to control the Northern Division. The tasks would be primarily for the Department of District Services and Native Affairs but in these it would be assisted by specialist officers of the Departments of Health[,] Agriculture, Lands and Education. (Memorandum 1951)

On 31 January, Administrator Colonel Murray, together with Dr Gunther and Ivan Champion, again visited Higaturu, the third occasion on which senior administration staff had been able to do so (Murray Administrator 1951k). Access to Sangara Mission, however, remained problematic, and the three men would not visit the Higaturu area again together until 15 February. Floods and mudflows down the Ambogo River were becoming hazardous (Taylor 1958).

Dr N.H. 'Doc' Fisher, Taylor's superior, arrived at Popondetta on this day, and a seismograph was on its way from the BMR in Melbourne (Taylor 1951). Visual observations of the crater continued but all operations over the next few days were concentrated on the erection of housing and the installation of power for the seismograph at Sangara Rubber Plantation. The seismograph began recording good data at the observation post on 8 February (Taylor 1958). Fisher stayed in the Lamington and Rabaul areas for two weeks, helping to take some of the workload off Taylor, engaging in important discussions with the administrator and participating in volcanological fieldwork (Figure 5.6).

Tony Taylor up to this time had had to work without any supporting volcano-monitoring instruments, such as a seismograph, in a situation in which, originally, he also knew nothing about the geology of Lamington volcano and, therefore, its past eruptive behaviour. Nevertheless, he had, by this time, gained the confidence and respect of the administrator and others, as well as the authority to control the movements of burial parties and others into what he decided were vulnerable areas at high-risk times. His numerous aerial inspections in aircraft flown by adventurous pilots to, and over, the active crater were no less striking. Indeed, observations from aeroplanes using binoculars and a camera probably provided his greatest opportunity for making volcanological advances during these early days, combined with intuition and a framework of professional volcanological knowledge. 


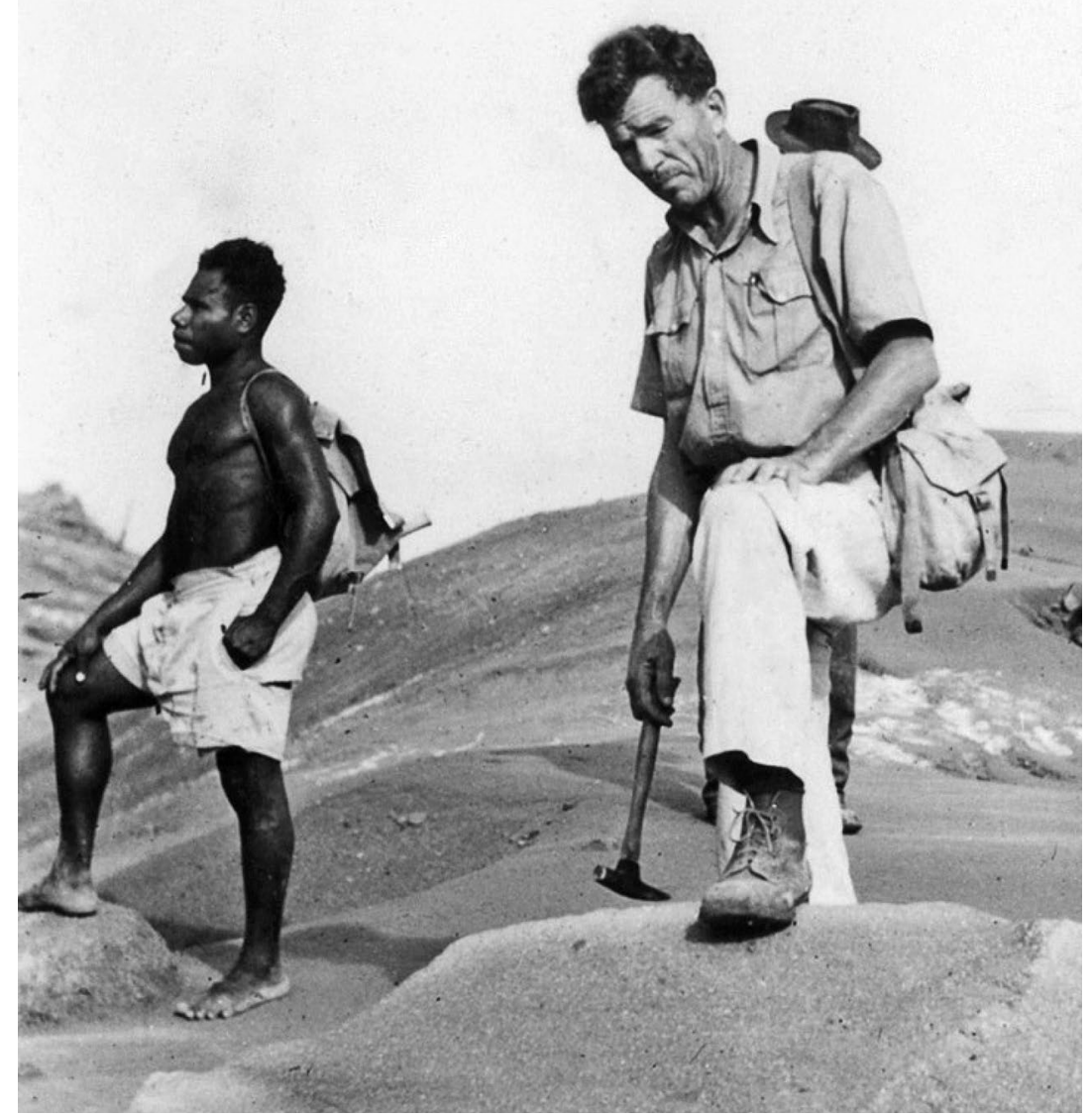

Figure 5.6. Dr Fisher and Leslie Topue during fieldwork in the disaster area

Dr N.H. Fisher (right) and field assistant Leslie Topue are here photographed undertaking fieldwork in the Lamington disaster area in early February 1951. Fisher appears to be thinking about collecting a rock sample with his small geological hammer from the large lava block under his left foot. Photograph supplied courtesy of Geoscience Australia (negative number GB/3236).

Taylor for over a week had been tracking the changes to the crater floor at Lamington as a result of his aerial inspections (Taylor 1951). Explosive eruptions on Thursday 25 January had created a smooth conical depression in the previously debris-filled crater, but within 24 hours uplift of the crater floor had created a shallow basin and new vents and, by 30 January, the uplifted floor was almost flat (Taylor 1958). Bulging started to produce large curved and smaller concentric cracks on the last day of January. Uplift and bulging were evidently being caused by a new 
body of active magma rising beneath the crater floor. This might be one of the reasons why Taylor had been so cautious about letting people into the area he had declared prohibited, because the new magma, once it broke through, conceivably might produce further devastating explosive eruptions. However, and as Taylor soon recognised, the features that he had been witnessing signalled the birth of a new lava dome on Lamington volcano in which magma of high viscosity — that is, low fluidity—remains plastic in the volcano conduit but then solidifies rapidly after the lava emerges onto the surface. Dome growth would escalate in the first week of February and from this time on it would be a defining characteristic of the Lamington eruption (Figures 5.7-5.8). This growth, however, would be interrupted and become complicated for another two months by repeated explosive eruptions from vents in the crater, some of which at times partly destroyed the developing dome (Taylor 1958).

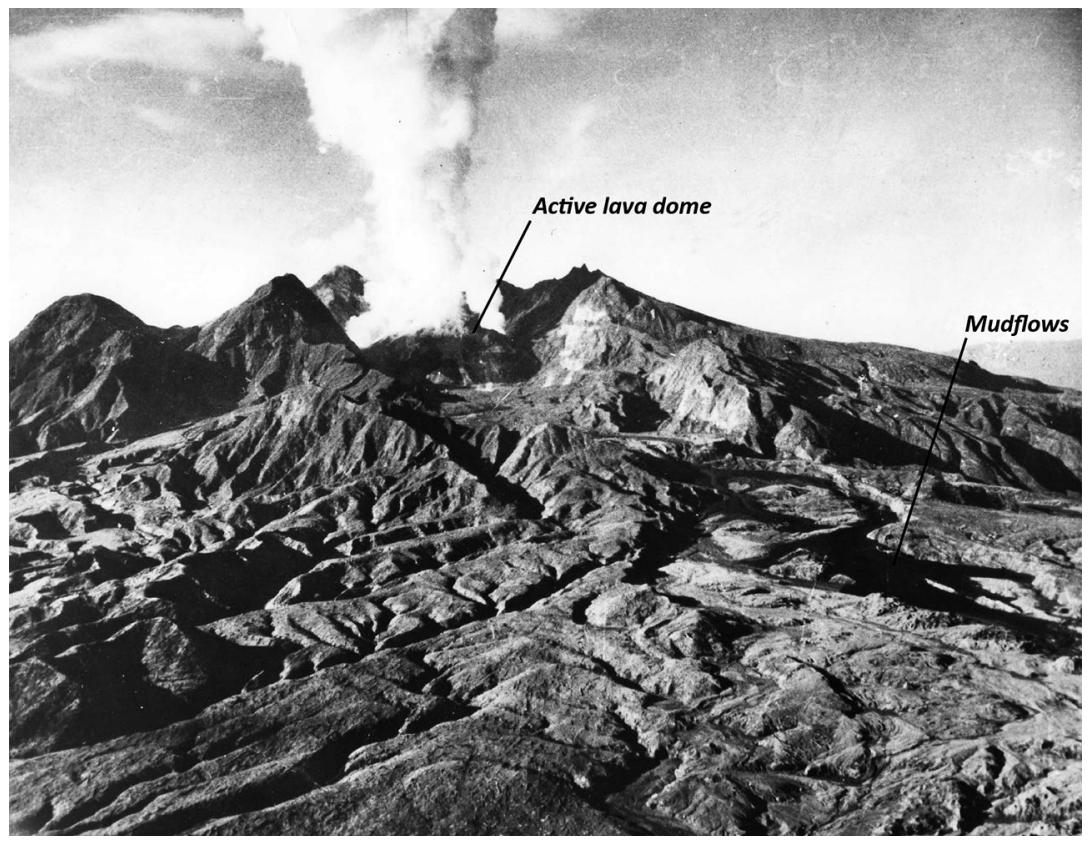

Figure 5.7. Aerial photograph of Lamington from the north on 8 February 1951

The devastated area dominates the foreground of this photograph and extends back to the breached crater of the volcano where the early stages of growth of the active, vapouremitting lava dome can be seen. Visible dome growth was especially rapid between 2 and 9 February. The dark areas on the right are mudflows of originally hot ash on the north-east flanks of the volcano in tributaries of the Ambogo River. Old lava domes form the rugged summit of the mountain. The photographer was probably G.A.M. Taylor (1958, fig. 118). Photograph supplied courtesy of Geoscience Australia (negative number GA/9938). 


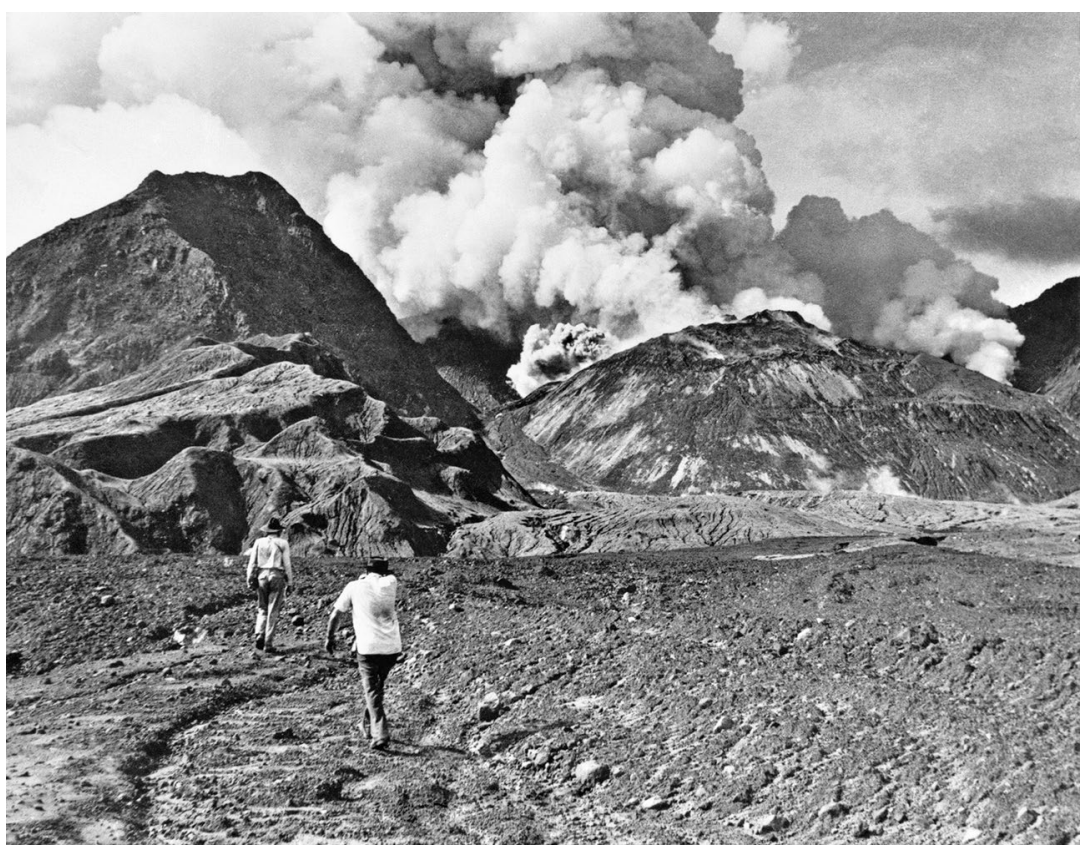

Figure 5.8. Taylor and Crellin approaching the active crater on 11 February 1951

Volcanologist Tony Taylor (in front) and Patrol Officer Bill Crellin are walking across recent pyroclastic flow deposits on a visit to the youthful lava dome crater near the head of the avalanche valley on 11 February 1951 (Taylor 1958, fig. 49). This photograph was taken by $\mathrm{Dr}$ Fisher. Some explosive activity is taking place on the south side of the dome, which is relatively small at this time (see, however, Figure 7.6). Photograph supplied courtesy of Geoscience Australia (negative number GB/3012).

\section{Newspapers and the Phillips Controversy}

'Doc' Fisher later wrote that the Lamington eruption of 1951:

Catapulted Taylor, normally one of the most reserved and retiring of men, into public prominence and provided the opportunity to put into effect the studies of the effects of volcanic eruptions of various types that he had been assiduously pursuing. (Fisher 1976, x)

Taylor's name soon appeared in newspapers and magazines as news of the Lamington disaster came to the attention of the news media and radio broadcasters, particularly in Australia. The names of other previously unknown Europeans appeared in the newspapers too, especially those 
of the dead whose bodies had been identified quickly and their next of kin informed. Also prominent were the names of evacuees met by the news media at Jacksons Airstrip in Port Moresby on their arrival from Popondetta.

News from Port Moresby was transferred to Australia quickly by radiogram and telephone, and press releases were provided by the Australian Government out of Canberra. There was a demand for photographs of the Higaturu-Sangara and Lamington area both before and after the eruption of 21 January, and especially of the eruption and volcano themselves (Figures 5.9-5.10). Captain Jacobson's aerial shots, for example, were popular. Comparisons were made between the catastrophic eruption cloud and the shape and 'blast' effects of the atomic bomb clouds of 1945, together with those of the atmospheric tests of nuclear bombs being undertaken at Bikini Atoll by the Americans. Rough sketch maps were published for the benefit of the many readers who would have had little idea of the locations of places such as Mount Lamington, Higaturu and Popondetta. Headlines were justifiably dramatic. These newspaper reports were the start of an accumulation of information about Lamington volcano and its 1951 eruption that would continue for many more decades as books, scientific papers, letters, opinion pieces, anniversary articles, memoirs and diaries became available.

The news media, therefore, played a vital role in the initial reporting on the disaster, although, as might be expected, quality varied and errors crept into some published articles - to the annoyance of those who had survived and knew otherwise. For example, early reporting in the February issue of the regional magazine Pacific Islands Monthly contained criticism about the lack of early warning of the catastrophic eruption, which drew the attention of the Department of External Territories in Canberra and of the administration in Port Moresby (e.g. Murray 1951a). Nevertheless, the administrator himself, in a reflective mood, wrote: 'One of my abiding memories is that of the courtesy and restraint of the journalists ... in this scene of disaster unparalleled in Australian history' (Murray 1968, 21). Colonel Murray also added his support to the Australian Broadcasting Commission (ABC) in Port Moresby following a protest letter that had been sent to the radio broadcaster by Bishop Strong. Words used in an $\mathrm{ABC}$ broadcast gave the false impression, to Bishop Strong at least, that Reverend Taylor had left his wife and children in order to get help. The manager for the $\mathrm{ABC}$ in Port Moresby, Glenister, discussed the matter at 
length with both Colonel Murray and Dr John Gunther. They concluded that the words did not 'brand' Reverend Taylor in a negative way, and the matter seems to have drawn to a close after Glenister wrote to both Bishop Strong and then to Ivan Champion (Glenister 1951).

The role of the news media, however, was not restricted to basic reporting but increasingly also to asking questions. How could so many people be killed by a mountain that was not even known to be a volcano? Was anyone responsible? Was there any truth in the words of the angry European women who arrived in Port Moresby in the days after the disaster had taken place?

A statement urging the establishment of a public inquiry into the lead-up to the Lamington disaster was published in the South Pacific Post, a weekly Port Moresby newspaper, on 2 February 1951 (Figure 5.9c(ii)). It was felt that the inquiry should be headed by an impartial and competent authority, such as Justice Gore, giving such committee the widest possible terms of reference for their investigation of the disaster' (South Pacific Post 1951c). Six questions were asked:

1. Had any action been taken before the first eruption to advise the Government Vulcanologist, G.A.M. Taylor, that earth tremors were being felt around Higaturu?

2. Had any members of the Higaturu-Sangara community, before the disastrous eruption, communicated their personal views and fears to any member of the Administration?

3. Did any of the native population who had previously had experience of volcanoes communicate their opinions and then flee the district?

4. What prevented the vulcanologist from arriving at the scene until 4,000 people had been wiped out?

5. What were the factors that led Mr Justice Phillips into making a decision not to evacuate Higaturu?

6. Was the Administration aware that for many weeks before the eruption earth tremors were continually being experienced in the area? (South Pacific Post 1951c) 


\section{FYCIISI|F Dnly picture taken of Mt. Lamington as the actual explosion occurred}

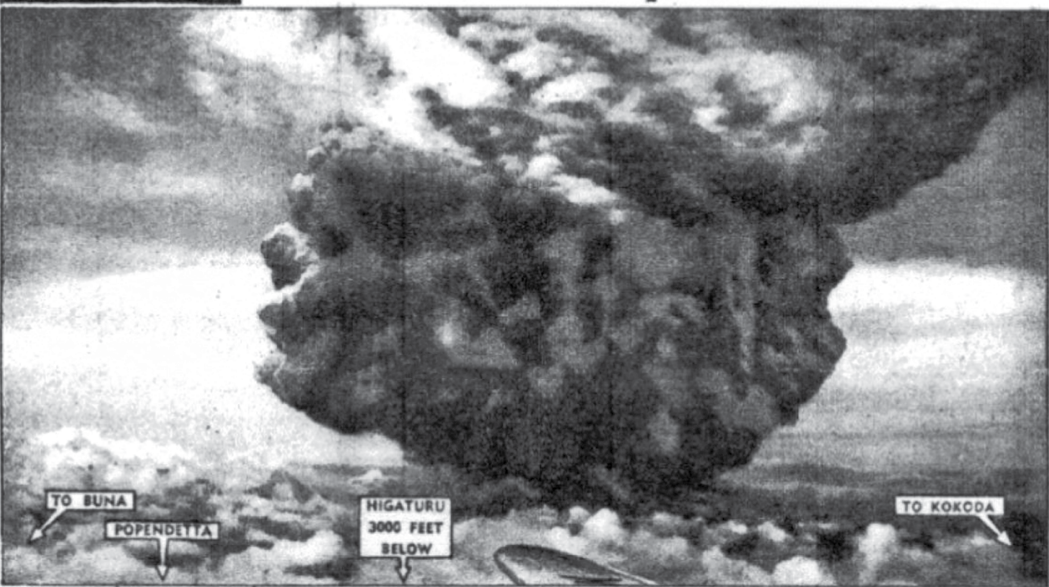

i

VOLCANO: 34

WHITES

MISSING

Missionary Dead: 30 Natives Feared Killed Or Burned
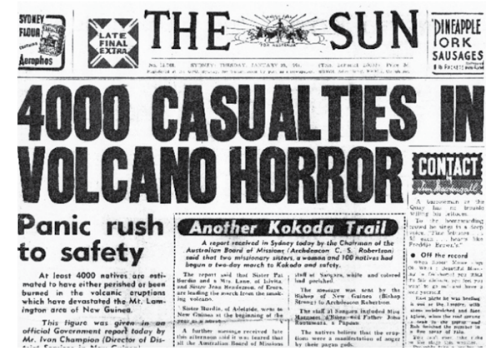

iii

Thirty four Europeans are missing as a result of the vol canic eruption at Mount Laming
Territory Administration anTerritory Admingt
nounced today.
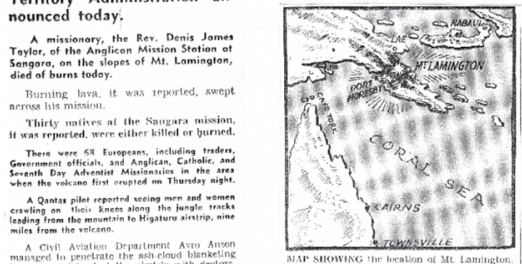

ii

Figure 5.9a. Headline cuttings representing only a small number of the many articles that were published on the Lamington disaster in different Australian and Port Moresby newspapers

i. Sunday Sun and Guardian (Sydney), Sunday 28 January 1951, 3. This photograph of the 'cauliflower'-shaped eruption cloud was taken by Captain Arthur Jacobson on 21 January shortly before the collapse of the cloud, as seen in Figure 4.5.

ii. Herald (Melbourne), Monday 22 January 1951, 1. Note that this article was published in an Australia newspaper only one day after the catastrophic eruption on 21 January 1951.

iii. Sun (Sydney), Tuesday 23 January 1951, 1. The statistic of '4000 casualties' represents only the very first estimate from the devastated area. 


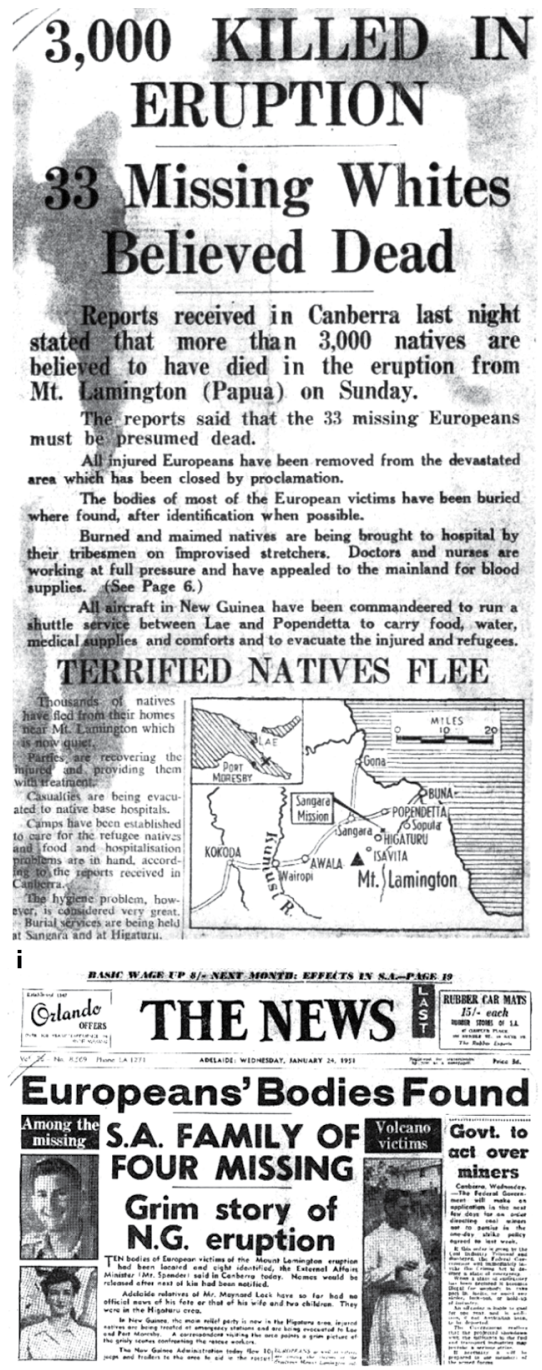

iii
JEW GUINEA DISASTER

\section{Havoc Likened to Atom Blast}

Reports filtering through to the Department of External Territories, Canberra, list 33 Europeans, mostly Australians, missing and fears for their safety mount every hour.

Air circuits of the volcano have shown 20 villages badly damaged and no sign of life. Latest reports state the dis- $/$ the 20 wrecked villages about
turbance is abating and it is the base of the mountaln. relieved that the major erup- Following on his filght he
lon in the mountain has burnt
issued orders for parties to tself out.
toln the mountain has burnt issued orders for parties to go
out and bury the dead and One report from the Direc- survey the damage

A continuous airlift is bein him as likening the devasta- maintained with Popandetta, tion about Lammaton as siml- tated area. Planes ore conlar to that caused by the stantly leaving Lae airstrip The bop cath supplys.

The report states trees have A terrific rainstorm which rooted and stripped of follage, ed away and may be travellin while native villages are blast- towards the volcano area aled with roofs torn off and though pilots reported flying All the trees were blown Popandetta as good. tion-sloping away from Lam- Dr. Gunther. who was at ington-an indication of the damage there was slight and Intensity of the blast. all Europeans were safe.
Plasma, food. clothing and
He sald he was making arrushed to the stricken area. natives in the area evacuated. ii

\section{Missing Man Took This Picture}

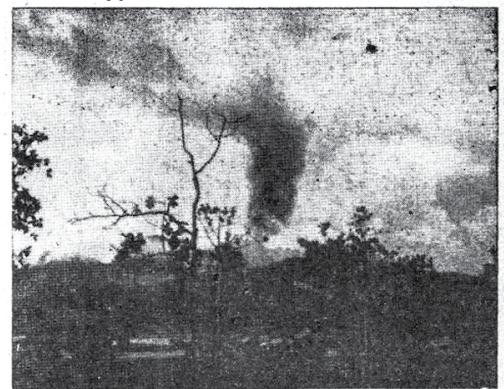

This dramatic picture of Mount Lamington's first eruption last Thursday was taken by young Works and Housing employee Kevin Woiwood, who is now listed among the missing. Woiwood's picture appeared in national news. papers throughout Australia. As far as is known it is the only photograph of the original eruption.

iv

Figure 5.9b. Four additional newspaper headlines

i. Sydney Morning Herald, Wednesday 24 January 1951, 1. The estimate of '3000 killed' is very close to the final death toll calculated weeks later.

ii. Bendigo Advertiser, Wednesday 24 January 1951, 2. Claimed similarities between the volcanic eruption of 21 January and atomic bomb explosions or 'blasts' was a common misconception in the early days of the relief and recovery phase.

iii News (Adelaide), Wednesday 24 January 1951, 1. Some emphasis is given to South Australian losses in this Adelaide newspaper.

iv. South Pacific Post (Port Moresby), Friday 26 January 1951, 1. Kevin Woiwod took this photograph from Higaturu of the eruption cloud at Mount Lamington on Thursday 17 January 1951, just three days before he was killed by the catastrophic eruption of Sunday 21 January. 


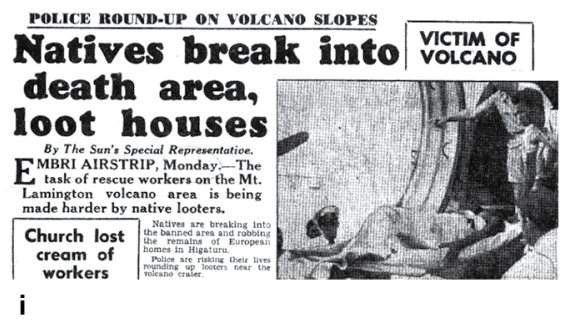

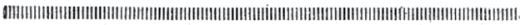

\section{Full Inquiry Is Essential}

THE enormity of the missioner Cowley, the reIf 0 un $\mathrm{t}$ Lamington latives of the dead, the disaster at first shocked survivors, the Arlministrathe people of this Terri-tion in general and to tory into silence; there those of the Territory was thonght only for the who still live in the vol victims and the bereaved. canic belt

Gradually however, the We therefore strongly details of the tragedy mo urge the Administrato folded and, naturally to immediately appoint a enough, events leading up committere headed by an to the tragedy and not the impartial and competent tragedy itself became the authority, such as Mr main topie. Justice Gore. giving such

tmong other things committee the widest pos residents talked of the sible terms of reference fact that Mr. Justice Phil- for their investigation of Jips, then Acting Admin- the disaster.

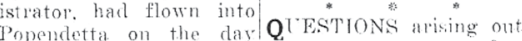
Popendetta on the day $Q$ of such terms of refer hapulescly oruted should include the after a discussion with following

after a discussion with 1. What were the factor Distriet Commissioner that led Mre. Justice comler, decided against Phillos into maleing evacuation.

TO add fuel to this ate Higaturu.

spreading fire of pub- 2. Was the Administra lic curjosity und, in some tion arare that for

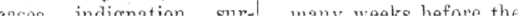

ii

\section{Figure 5.9c. Four more newspaper headlines}

i. Sun News-Pictorial (Melbourne), Tuesday 30 January 1951, 9. Looting at Higaturu is headlined in this article.

ii. South Pacific Post (Port Moresby), Friday 2 February 1951, 1. The need for an inquiry into the Lamington disaster was highlighted on the front page of this newspaper published in Port Moresby.

iii. Age (Melbourne), Thursday 1 February 1951, 4. Volcanologist John Best is quotedperhaps misquoted and out of context-as saying in Lae on Wednesday 31 January that the worst of the eruptions at Mount Lamington was over and that the volcano 'may never erupt seriously again'.

iv. North Queensland Register (Townsville), Saturday 3 March 1951, 15. Two RAAF 'Mosquito' aircrew undertaking the aerial photography survey of Mount Lamington are photographed for this article in which attention is drawn to the poor visibility that was hindering the aerial surveying of the Lamington area. 
Minister for the Department of External Territories Percy Spender and his advisers in Canberra had already heard about the rising public and media disquiet and that same day, 2 February, they released a long statement for the press defending the actions of Judge Phillips and the administration in Port Moresby. 'We can all be wise after the event', said Spender, ending his press release with:

\begin{abstract}
The whole of the facts and attendant circumstances relating to the eruption will, of course, be carefully scrutinised so as to learn from them all lessons that may be learned. I do not, however, see any grounds whatever for any public enquiry. Generally I think the Administration has done a very good job and would personally like to pay a public tribute to the zeal and devotion displayed not only by it but by many others, in dealing with this awful and devastating disaster. (Spender 1951a, 3)
\end{abstract}

Much of the ministers' statement was published in the February issue of Pacific Islands Monthly in an article entitled 'Why No Official Warning? Demand for Inquiry about Lamington Disaster'. It contained the following statement:

The local newspaper, South Pacific Post, has soberly but strongly voiced the people's demand for an inquiry. 'What is the use of maintaining a vulcanological service in the Territory if no attempt is made to study volcanoes outside of Rabaul?' sums up the viewpoint of the ordinary man. (Pacific Islands Monthly 1951c, 10)

The administration, as noted by the minister, had indeed undertaken outstanding relief work in the aftermath of the disaster. Further, there was recognition not only of this achievement but also of some opposition from the general public to the idea of an inquiry, if published letters by W. Kienzle (South Pacific Post 1951d) and T.W. Upson (South Pacific Post 1951e) are representative. No official inquiry took place, but questions continued to be asked concerning events before the catastrophic eruption of 21 January. Judge Phillips was still under scrutiny and was anxious to defend himself. On 3 February 1951 he wrote a detailed, 10-page memorandum, which included three appendices, to the Administrator Colonel Murray (Deputy Administrator 1951; see also Phillips 1951b). This report was forwarded to the minister in Canberra. Spender and his advisers were not totally convinced, however, and the minister responded on 13 February as follows: 
I desire to have followed up why no action appears to have been taken when Mr Cowley at least suggested that 'someone should go in and take a look' (18.1.51). Was Judge Phillips visit at all connected with this[?] I am not completely satisfied on this aspect particularly in view of [the] fact that Cowley clearly expected a vulcanologist to arrive. (Spender 1951b)

Judge Phillips in his response of 27 February to this ministerial instruction said that he had no knowledge of the radio call from Cowley when he made the 'entirely spontaneous' decision on Thursday 18 January to fly to Higaturu (Phillips 1951c, 1). Perhaps the minister or his advisers could have explored further whether Judge Phillips, because of his previous experience with volcanic eruptions at Rabaul in 1937, thought that he was adequately qualified to deal with the reports from Higaturu of the volcanic eruptions at Lamington. Why did he not delegate the task to the administration's own volcanologist in Rabaul? However, in reality, this would have made little difference, as Tony Taylor would have had to travel to Popondetta, at the very earliest, on Friday 19 January-the day he said he heard about the Lamington unrest—assuming that a flight from Rabaul, and a connecting flight to Popondetta, had been available. On arrival at Popondetta, Taylor would have had insufficient time to make any sort of reasonable evidence-based forecast of the terrible events that followed the next morning of Sunday 21 January. Indeed, he likely would have been killed himself had he decided to base himself at Higaturu and to undertake observational fieldwork on the volcano.

Judge Phillips, in his reply of 27 February, also reported on what more he had found out about the radio-telephone conversation between Cowley in Higaturu and Samson in Port Moresby on Thursday 18 Januarythat is, the exchange that had been so difficult to understand because of the radio static apparently being caused by the volcanic activity at Lamington. Sansom, on 29 January, had handed Deputy Administrator Phillips a memorandum stating: 1) that a 24-hour emergency radio call arrangement had been put in place at that time; and 2) that 'Mr Cowley stated that he did not consider there was any cause for alarm, but that in the event that the situation changed, he would immediately forward advice through the emergency communication' (Phillips 1951c, 2). However, Phillips was also advised by the government secretary's office on 1 February that Jefford, who had monitored and assisted at the radiotelephone call on 18 January, reported that Cowley had indeed said 'that someone should go in and have a look' (2). 


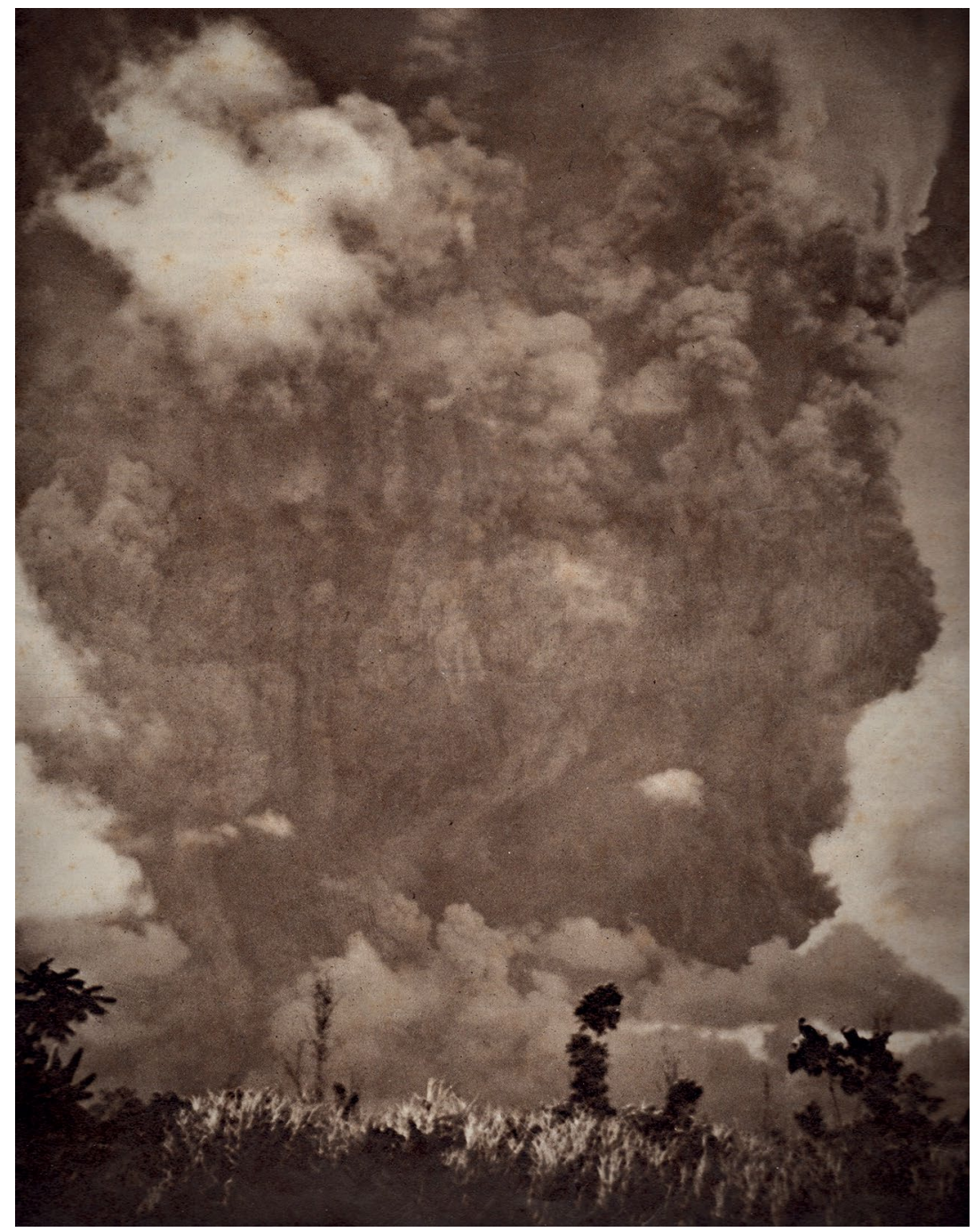

Figure 5.10. Photograph of Lamington in full eruption

This dramatic and probably trimmed photograph of Mount Lamington in eruption was published in sepia on the large-format front cover of the Illustrated London News on Saturday 24 February 1951. The dense, wide eruption column appears ready to collapse and so form pyroclastic flows. This volcanic activity is dated Saturday 18 February and is described in the caption of the published photograph as the 'second eruption'. This is somewhat misleading as other significant explosive eruptions took place between 21 January and 18 February (see Taylor 1958). The name of the photographer is unknown, as is the precise time of day that the photograph was taken. Taylor (1958) did not use this photograph in his BMR Bulletin. Note that 18 February is only six days before the date of publication of the magazine in London, meaning that the photograph must have been transported expressly by air from Papua to the British capital. 
Three particular points can be made with regard to the available documentation: 1) administration officers more senior than Samson and Jefford were evidently not informed of Cowley's request for assistance on 18 January; 2) there is no specific mention in any of the correspondence, even in Judge Phillips' detailed reports, of the need for the Territory's own government volcanologist in Rabaul to be advised of the Lamington volcanic activity, even though the administrator himself, Colonel Murray, would be in Rabaul the next day; 3) there appears to have been no dire urgency or any official formality in the request made by Cowley, even though he clearly expected a volcanologist to arrive at Popondetta airstrip on Friday 19 January.

There is also a suspicion that the poor communications between Port Moresby and Rabaul may have been influenced in part by a residual polarisation of loyalties between matters 'Papuan' and matters 'New Guinean' when the two territories were separate entities. Murray, however, who was in Rabaul anyway, would not have been impressed if this indeed had been the case. Why did Phillips not contact Murray by radio-telephone and why was the district commissioner in Rabaul, Keith McCarthy, evidently reluctant to let Tony Taylor leave for Lamington when he first heard about the volcanic unrest, if the later account of events by John Best is true?

One additional point can be offered with regard to the decision not to evacuate made on 18 January by Judge Phillips and Reverend Dennis Taylor-and secondarily by their subordinates Cowley and Reverend Porter: the contrast between the reactions and responses of European men and women. The men seem to have adhered to the principal of staying calm and not appearing fearful in the face of danger, bringing to mind the British wartime expression 'keep calm and carry on', which carries a hint of fatalism and is not necessarily the best advice when facing an unknown, yet escalating, volcanic threat. An antithetic slogan is 'don't wait for what happens next'. The European women were justifiably frightened by the volcanic displays at Mount Lamington and what they might portend, but their human responses both before and after the disaster were treated, by at least some of their male counterparts, as emotional and irrational. These times, one is obliged to note, were dominated by masculinityan admiration of male self-reliance and probably (and understandably) male militaristic sentiments left over from the war and from ANGAU (i.e. Australian New Guinea Administrative Unit) times. 
This text is taken from Roars from the Mountain: Colonial Management of the 1951 Volcanic Disaster at Mount Lamington, by R. Wally Johnson, published 2020 by ANU Press, The Australian National University,

Canberra, Australia.

doi.org/10.22459/RM.2020.05 